\title{
Metal Recovery Using Oxalate Chemistry: A Technical Review
}

\author{
Ankit Verma, $^{\dagger, \ddagger(0)}$ Rajkumar Kore, ${ }^{\dagger, \ddagger \subset}$ David R. Corbin, ${ }^{\ddagger}$ and Mark B. Shiflett ${ }^{*} \dagger, \ddagger \odot$ \\ ${ }^{\dagger}$ Department of Chemical and Petroleum Engineering, University of Kansas, 1530 West 15th Street, Lawrence, Kansas 66045, \\ United States \\ ${ }^{\ddagger}$ Center for Environmentally Beneficial Catalysis, University of Kansas, 1501 Wakarusa Drive, Lawrence, Kansas 66047, United \\ States
}

\begin{abstract}
Energy-efficient metal recovery and separation processes from a mixture of valuable metals are vital to the metallurgy and recycling industries. Oxalate has been identified as a sustainable reagent that can provide both the desired selectivity and efficient leaching capabilities for a variety of mixed metals under mild reaction conditions. The oxalate process has a great potential to replace many of the existing metal recovery processes that use inorganic acids such as sulfuric, hydrochloric, and nitric acids. In this Review, the use of oxalate chemistry in four major metal recovery applications is discussed, namely, spent lithium-ion batteries, spent catalysts, valuable ores, and contaminated and unwanted waste streams. Recycling of critical and precious metals from spent lithium-ion batteries and catalysts has significant economic opportunities. For efficient metals recovery, reaction conditions (e.g., temperature, $\mathrm{pH}$, time, and concentration), metal-oxalate complex formation, oxidation and reduction, and metal precipitation must all be well-understood. This Review provides an overview from articles and patents for a variety of metal recovery processes along with insights into future process development.

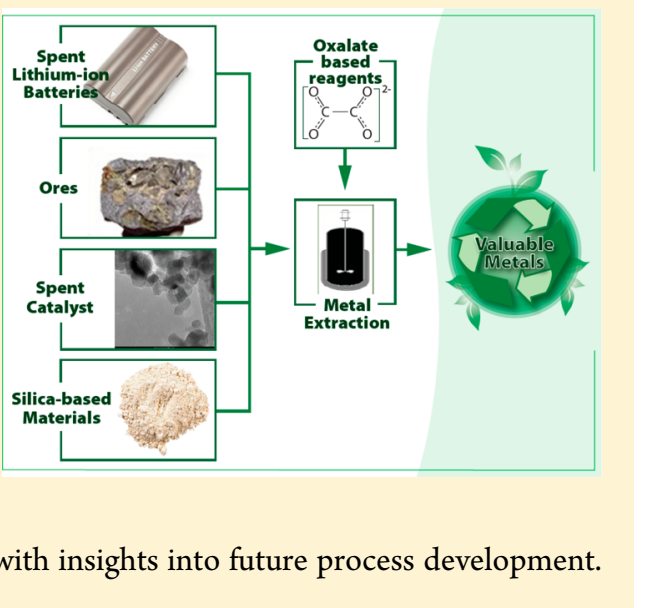

\section{INTRODUCTION}

The oxalate anion $\left(\mathrm{C}_{2} \mathrm{O}_{4}{ }^{2-}\right)$ is the conjugate base of oxalic acid $\left(\mathrm{H}_{2} \mathrm{C}_{2} \mathrm{O}_{4}\right)$, the simplest dicarboxylic acid. Oxalic acid is commercially available in the dihydrate form. Scheele first synthesized oxalic acid in 1776 by oxidation of sugar with nitric acid. In 1824, oxalic acid was synthesized by Wöhler by the hydrolysis of cyanogen. ${ }^{1,2}$ In nature, it is formed by an enzymatic pathway for hydrolysis of oxaloacetates in Aspergillus niger, fungi (aspergillium), bacteria (acetobacter), and mammals by carbohydrate metabolism via the tricarboxylic acid cycle. ${ }^{3-5}$ The urine of humans and most mammals contains a small amount of oxalate, usually bound to calcium. An increase in the concentration of calcium oxalate content can lead to the formation of kidney stones. Industrially, oxalate is typically used as a rust remover in metal treatment, a precipitant in rare earth extraction processes, and a mordant for printing and in the dyeing of cotton and wool, tanning and bleaching of leather, bleaching of pulpwood, and synthesis of esters and salts. $^{6-8}$

Depending on the $\mathrm{pH}$, oxalic acid can exist in solution as several different species $\left(\mathrm{H}_{2} \mathrm{C}_{2} \mathrm{O}_{4}, \mathrm{HC}_{2} \mathrm{O}_{4}{ }^{-}, \mathrm{C}_{2} \mathrm{O}_{4}{ }^{2-}\right)$. The structure of the oxalate anion is shown in Figure $1 . \mathrm{H}_{2} \mathrm{C}_{2} \mathrm{O}_{4}$ is the predominant species below $\mathrm{pH} 1.23$, and $\mathrm{C}_{2} \mathrm{O}_{4}{ }^{2-}$ is the dominant species at $\mathrm{pH} 4.19$ or greater. The oxalic acid speciation curve, shown in Figure 2, was created by performing the mole balance around the $\mathrm{pK}_{\mathrm{a}}$ values of oxalic acid. The oxalate ion (IUPAC: ethanedioate ion) is a bidentate anionic ligand that can donate two pairs of electrons to a metal ion. Also, this ligand is commonly known as a chelate because of its ability to attach to a metal cation in two places. There has been

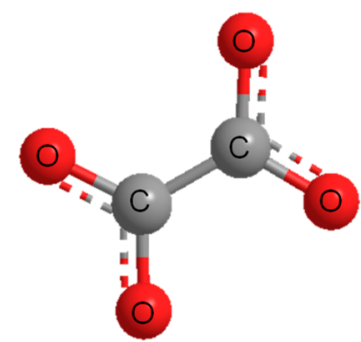

Figure 1. Structure of oxalate anion.

tremendous interest in the study of oxalates as a precipitant, chelating agent, and reducing agent. ${ }^{2}$ Most of the simple oxalate compounds (like $\mathrm{FeC}_{2} \mathrm{O}_{4} \cdot 2 \mathrm{H}_{2} \mathrm{O}$ ) are insoluble in water, but with excess oxalate the possibility of forming various oxalate complexes (i.e., $\mathrm{Fe}\left(\mathrm{C}_{2} \mathrm{O}_{4}\right)_{2}{ }^{2-}$ ) widens the application of oxalates as leaching agents. In a metal complex ion, a metal center is present with a number of ligands attached via a coordinate bond, providing a net cationic or anionic charge, whereas a compound is formed by two or more elements connected via a covalent or ionic bond. As a precipitating agent, oxalate has historically been used in rare earth extraction processes. ${ }^{8,9}$ Oxalate/oxalic acid can also be used as a mild reducing agent with the following oxidation reaction: ${ }^{10}$

Received: May 13, 2019

Revised: July 10, 2019

Accepted: July 31, 2019

Published: July 31, 2019 


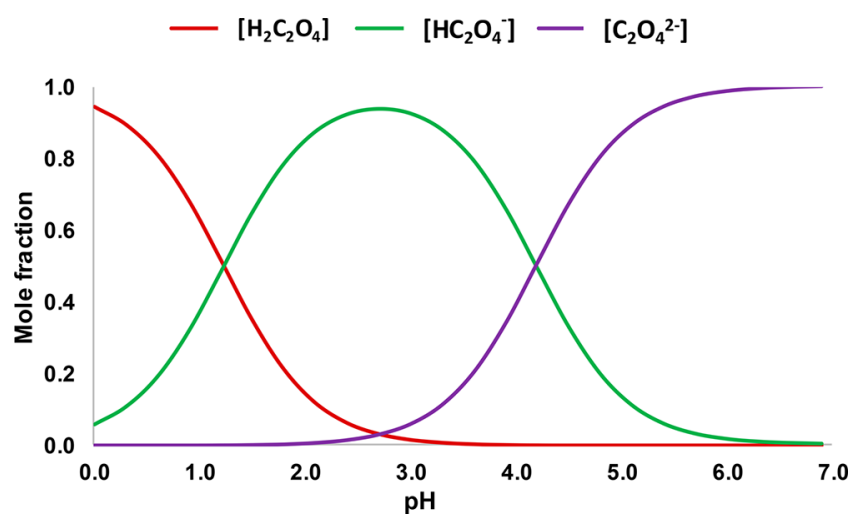

Figure 2. Oxalic acid speciation as a function of $\mathrm{pH}\left(\mathrm{p} K_{\mathrm{a} 1}=1.23\right.$ and $\left.\mathrm{pK}_{\mathrm{a} 2}=4.19\right)$ at room temperature.

$$
\mathrm{C}_{2} \mathrm{O}_{4}^{2-} \leftrightarrows 2 \mathrm{CO}_{2}+2 \mathrm{e}^{-} \quad E^{\circ}=0.49 \mathrm{~V}
$$

This positive potential indicates the thermodynamic feasibility of this oxidation reaction and provides a possibility where it can potentially reduce a metal ion. Oxalate has been reported to reduce $\mathrm{Co}(\mathrm{III})$ to $\mathrm{Co}(\mathrm{II})$ and $\mathrm{Fe}(\mathrm{III})$ to $\mathrm{Fe}(\mathrm{II}) .{ }^{11-15}$ This reduction property can affect the leaching efficiency, particularly when solubility changes with the reduction of the metal. This kind of variation in solubility is seen commonly with the iron oxalate complexes where iron(III) oxalate is soluble, but iron(II) oxalate is insoluble. ${ }^{13-15}$

Most metals form either simple oxalate compounds or oxalate complexes, or both. Simple oxalate compounds can be either water-soluble (like $\mathrm{Li}_{2} \mathrm{C}_{2} \mathrm{O}_{4}$ ) or insoluble (like $\mathrm{FeC}_{2} \mathrm{O}_{4}$. $2 \mathrm{H}_{2} \mathrm{O}$ ), depending on the metal-ligand interactions, whereas all oxalate complexes are water-soluble. The increase in the solubility of simple oxalate compounds in the presence of excess oxalate provides the basis for formation of oxalate complex. ${ }^{2,16}$ Most of the oxalate complexes formed by various metals are summarized in Table 1. Figure 3 summarizes the literature on the tendency of metals to form simple oxalate compounds and/or oxalate complexes. As might be expected all of the alkali metals (Group 1) are reported to form only soluble oxalate compounds. Many of the simple oxalate compounds are reported to be insoluble with their solubilities

\section{Table 1. Classification of Metal Oxalate Complexes ${ }^{a}$}

\begin{tabular}{|c|c|c|}
\hline $\begin{array}{l}\text { no. of } \\
\text { oxalate } \\
\text { ligands } \\
\text { attached }\end{array}$ & $\begin{array}{l}\text { formula of } \\
\text { species }\end{array}$ & metal ion $(\mathrm{M})$ \\
\hline 1 & $\mathrm{M}\left(\mathrm{C}_{2} \mathrm{O}_{4}\right)^{+}$ & $\begin{array}{l}\mathrm{Al}(\mathrm{III}), \mathrm{Fe}(\mathrm{III}), \mathrm{Sb}(\mathrm{III}), \mathrm{Cr}(\mathrm{III}), \mathrm{Y}(\mathrm{III}), \mathrm{Yb}(\mathrm{III}) \\
\quad \mathrm{Ce}(\mathrm{III}), \mathrm{Mn}(\mathrm{III}), \mathrm{In}(\mathrm{III}), \mathrm{Nd}(\mathrm{III}), \mathrm{Tb}(\mathrm{III})\end{array}$ \\
\hline 1 & $\mathrm{M}\left(\mathrm{C}_{2} \mathrm{O}_{4}\right)^{-}$ & $\mathrm{Ag}(\mathrm{I}), \mathrm{TiO}^{+}, \mathrm{Tl}(\mathrm{I}), \mathrm{MoO}^{2+}$ \\
\hline 2 & $\mathrm{M}\left(\mathrm{C}_{2} \mathrm{O}_{4}\right)_{2}^{-}$ & $\begin{array}{l}\mathrm{Al}(\mathrm{III}), \mathrm{Y}(\mathrm{III}), \mathrm{Yb}(\mathrm{III}), \mathrm{Cr}(\mathrm{III}), \mathrm{In}(\mathrm{III}), \mathrm{Rh}(\mathrm{III}), \\
\mathrm{Mn}(\mathrm{III}), \mathrm{Sb}(\mathrm{III}), \mathrm{Ir}(\mathrm{III}), \mathrm{Fe}(\mathrm{III}), \mathrm{Ce}(\mathrm{III}), \mathrm{Po}(\mathrm{III}), \\
\mathrm{Co}(\mathrm{III}), \mathrm{Nd}(\mathrm{III}), \mathrm{Pu}(\mathrm{III}), \mathrm{Ga}(\mathrm{III}), \mathrm{Gd}(\mathrm{III})\end{array}$ \\
\hline 2 & $\mathrm{M}\left(\mathrm{C}_{2} \mathrm{O}_{4}\right)_{2}^{2-}$ & $\begin{array}{l}\mathrm{Be}(\mathrm{II}), \mathrm{Co}(\mathrm{II}), \mathrm{Pt}(\mathrm{II}), \mathrm{Mg}(\mathrm{II}), \mathrm{Ni}(\mathrm{II}), \mathrm{TiO}^{2+} \\
\mathrm{Ca}(\mathrm{II}), \mathrm{Cu}(\mathrm{II}), \mathrm{VO}^{2+}, \mathrm{Sr}(\mathrm{II}), \mathrm{Zn}(\mathrm{II}), \mathrm{OsO}_{2}{ }^{2+} \\
\mathrm{Ba}(\mathrm{II}), \mathrm{Cd}(\mathrm{II}), \mathrm{Mn}(\mathrm{II}), \mathrm{Pb}(\mathrm{II}), \mathrm{Fe}(\mathrm{II})\end{array}$ \\
\hline 3 & $\mathrm{M}\left(\mathrm{C}_{2} \mathrm{O}_{4}\right)_{3}{ }^{2-}$ & Ge(IV), Ir(IV), Pu(IV), Ru(IV), Th(IV) \\
\hline 3 & $\mathrm{M}\left(\mathrm{C}_{2} \mathrm{O}_{4}\right)_{3}{ }^{3-}$ & $\begin{array}{l}\mathrm{Al}(\mathrm{III}), \mathrm{Co}(\mathrm{III}), \mathrm{Ir}(\mathrm{III}), \mathrm{Sc}(\mathrm{III}), \mathrm{Ga}(\mathrm{III}), \mathrm{Ce}(\mathrm{III}), \\
\text { V(III), Y(III), Cr(III), Sb(III), Pu(III), Mn(III), } \\
\text { Ru(III), } \mathrm{Fe}(\mathrm{III}), \mathrm{Rh}(\mathrm{III})\end{array}$ \\
\hline 3 & $\mathrm{M}\left(\mathrm{C}_{2} \mathrm{O}_{4}\right)_{3}^{4-}$ & $\mathrm{Co}(\mathrm{II}), \mathrm{Zn}(\mathrm{II}), \mathrm{Ni}(\mathrm{II})$ \\
\hline 4 & $\mathrm{M}\left(\mathrm{C}_{2} \mathrm{O}_{4}\right)_{4}^{4-}$ & $\mathrm{Sn}(\mathrm{IV}), \mathrm{Hf}(\mathrm{IV}), \mathrm{U}(\mathrm{IV}), \mathrm{Zr}(\mathrm{IV}), \mathrm{Th}(\mathrm{IV}), \mathrm{Pu}(\mathrm{IV})$ \\
\hline 4 & $\mathrm{M}\left(\mathrm{C}_{2} \mathrm{O}_{4}\right)_{4}{ }^{5-}$ & $\mathrm{Pu}(\mathrm{III})$ \\
\hline
\end{tabular}

${ }^{a}$ From ref 2.

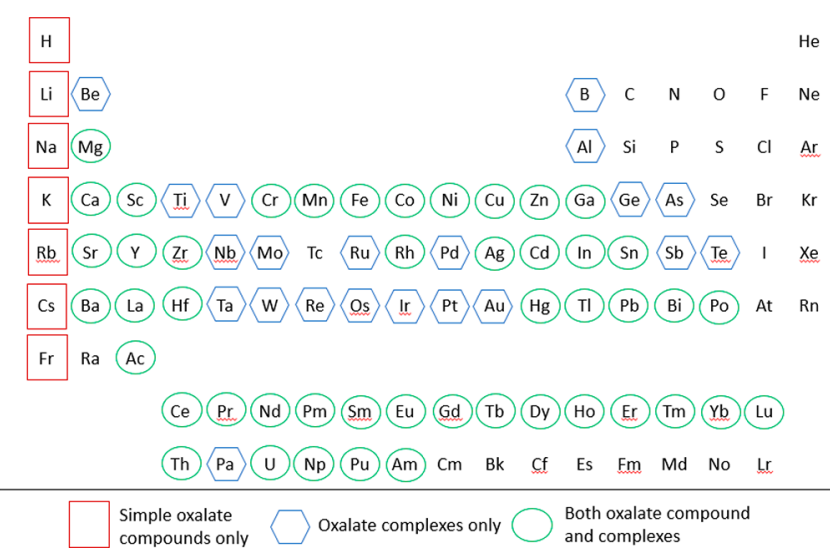

Figure 3. Tendency of metals to form simple oxalate compounds and/or complex oxalates. ${ }^{2}$

ranging from $10^{-1}$ to $10^{-30} \mathrm{~g} / 100 \mathrm{~mL}$ water. ${ }^{2,17,18}$ Table 1 summarizes the possible metal oxalate complexes, and Table 2 classifies the insoluble and soluble oxalate compounds formed by most of the metals.

Table 2. Qualitative Solubility of Common Oxalate Compounds in Water at $25{ }^{\circ} \mathrm{C}^{a}$

\begin{tabular}{|c|c|}
\hline formula & ref \\
\hline \multicolumn{2}{|c|}{ Insoluble } \\
\hline $\mathrm{Ac}_{2}\left(\mathrm{C}_{2} \mathrm{O}_{4}\right)_{3} \cdot 10 \mathrm{H}_{2} \mathrm{O}$ & 17 \\
\hline $\mathrm{Al}_{2}\left(\mathrm{C}_{2} \mathrm{O}_{4}\right)_{3} \cdot \mathrm{H}_{2} \mathrm{O}$ & 18 \\
\hline $\mathrm{BaC}_{2} \mathrm{O}_{4}$ & 24 \\
\hline $\mathrm{Bi}_{2}\left(\mathrm{C}_{2} \mathrm{O}_{4}\right)_{3}$ & 18 \\
\hline $\mathrm{CdC}_{2} \mathrm{O}_{4}$ & 18 \\
\hline $\mathrm{CaC}_{2} \mathrm{O}_{4}$ & 18 \\
\hline $\mathrm{Ce}\left(\mathrm{C}_{2} \mathrm{O}_{4}\right)_{3} \cdot 9 \mathrm{H}_{2} \mathrm{O}$ & 18 \\
\hline $\mathrm{CoC}_{2} \mathrm{O}_{4} \cdot 2 \mathrm{H}_{2} \mathrm{O}$ & 18 \\
\hline $\mathrm{CuC}_{2} \mathrm{O}_{4} \cdot 0.5 \mathrm{H}_{2} \mathrm{O}$ & 18 \\
\hline $\mathrm{FeC}_{2} \mathrm{O}_{4} \cdot 2 \mathrm{H}_{2} \mathrm{O}$ & 18 \\
\hline $\mathrm{La}_{2}\left(\mathrm{C}_{2} \mathrm{O}_{4}\right)_{3} \cdot x \mathrm{H}_{2} \mathrm{O}$ & 17 \\
\hline $\mathrm{PbC}_{2} \mathrm{O}_{4}$ & 18 \\
\hline $\mathrm{MgC}_{2} \mathrm{O}_{4}$ & 18 \\
\hline $\mathrm{MnC}_{2} \mathrm{O}_{4} \cdot 2 \mathrm{H}_{2} \mathrm{O}$ & 18 \\
\hline $\mathrm{Hg}_{2} \mathrm{C}_{2} \mathrm{O}_{4}$ & 18 \\
\hline $\mathrm{HgC}_{2} \mathrm{O}_{4}$ & 18 \\
\hline $\mathrm{NiC}_{2} \mathrm{O}_{4} \cdot 2 \mathrm{H}_{2} \mathrm{O}$ & 18 \\
\hline $\mathrm{Ag}_{2} \mathrm{C}_{2} \mathrm{O}_{4}$ & 18 \\
\hline $\mathrm{SrC}_{2} \mathrm{O}_{4} \cdot 2 \mathrm{H}_{2} \mathrm{O}$ & 18 \\
\hline $\mathrm{SnC}_{2} \mathrm{O}_{4}$ & 18 \\
\hline $\mathrm{Y}_{2}\left(\mathrm{C}_{2} \mathrm{O}_{4}\right)_{3} \cdot 9 \mathrm{H}_{2} \mathrm{O}$ & 17 \\
\hline $\mathrm{ZnC}_{2} \mathrm{O}_{4} \cdot 2 \mathrm{H}_{2} \mathrm{O}$ & 18 \\
\hline \multicolumn{2}{|c|}{ Soluble } \\
\hline $\mathrm{BeC}_{2} \mathrm{O}_{4} \cdot 3 \mathrm{H}_{2} \mathrm{O}$ & 18 \\
\hline $\mathrm{CrC}_{2} \mathrm{O}_{4} \cdot \mathrm{H}_{2} \mathrm{O}$ & 18 \\
\hline $\mathrm{Fe}_{2}\left(\mathrm{C}_{2} \mathrm{O}_{4}\right)_{3}$ & 18 \\
\hline $\mathrm{Li}_{2} \mathrm{C}_{2} \mathrm{O}_{4}$ & 18 \\
\hline $\mathrm{K}_{2} \mathrm{C}_{2} \mathrm{O}_{4}$ & 18 \\
\hline $\mathrm{Na}_{2} \mathrm{C}_{2} \mathrm{O}_{4}$ & 18 \\
\hline $\mathrm{Ti}_{2}\left(\mathrm{C}_{2} \mathrm{O}_{4}\right)_{3} \cdot 10 \mathrm{H}_{2} \mathrm{O}$ & 17 \\
\hline $\mathrm{VOC}_{2} \mathrm{O}_{4}$ & 25 \\
\hline
\end{tabular}

${ }^{a}$ Compounds having solubility less than $0.1 \mathrm{~g} / 100 \mathrm{~mL}$ of water at 25

${ }^{\circ} \mathrm{C}$ are termed qualitatively insoluble. 


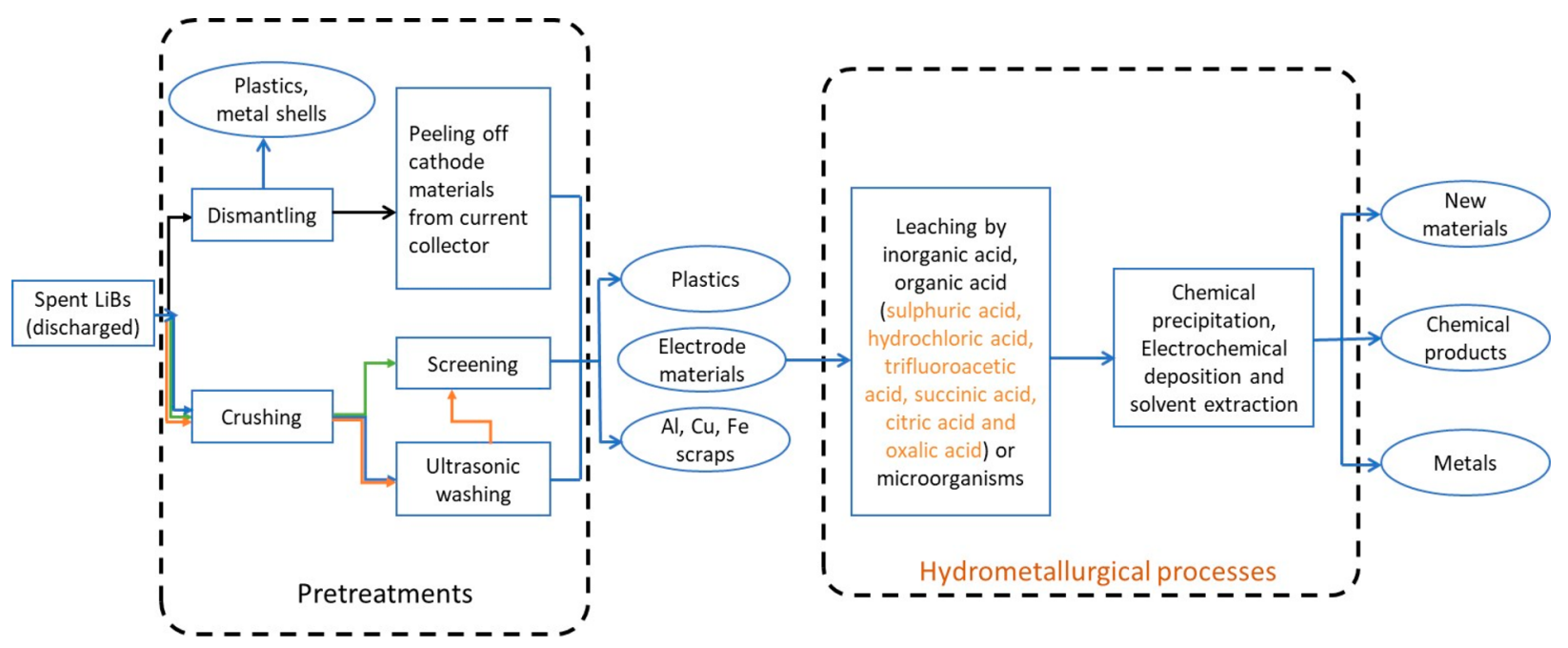

Figure 4. Flowchart of a typical process for recycling spent LIBs. ${ }^{39}$

Table 3. Summary of the Oxalic Acid Digestion Process with Different Cathode Materials

\begin{tabular}{|c|c|c|c|c|c|c|c|}
\hline \multirow[b]{2}{*}{ cathode material } & \multicolumn{5}{|c|}{ reaction conditions using oxalic acid } & \multirow[b]{2}{*}{ metal recovery (wt\%) } & \multirow[b]{2}{*}{ ref } \\
\hline & conc $(\mathrm{M})$ & temp $\left({ }^{\circ} \mathrm{C}\right)$ & solid-to-liquid ratio $(\mathrm{g} / \mathrm{L})$ & reaction time $(\mathrm{h})$ & rotation rate $(\mathrm{rpm})$ & & \\
\hline \multirow[t]{4}{*}{$\mathrm{LiCoO}_{2}$} & 3.0 & 80 & 50 & 1.5 & 300 & $\begin{array}{l}\mathrm{Li}, 99 \% \\
\mathrm{Co}, 96 \%\end{array}$ & 28 \\
\hline & 1.0 & 95 & 15 & 2.5 & 400 & $\begin{array}{l}\text { Co, } 97 \% \\
\text { Li, } 98 \%\end{array}$ & 11 \\
\hline & 1.0 & 80 & 50 & 2 & 300 & $\mathrm{Li}, 96 \%$ & 12 \\
\hline & 1.0 & 25 & 5 & 24 & 100 & $\mathrm{Li}, 74 \%$ & 30 \\
\hline NMC & 0.6 & 75 & 20 & 2 & - & $\begin{array}{l}\mathrm{Li}, 84 \% \\
\mathrm{Ni}, \mathrm{Mn}, \mathrm{Co}, 98 \%\end{array}$ & 40 \\
\hline NMC, bioleaching & 0.04 & 30 & 0.01 & 648 & 130 & $\begin{array}{l}\mathrm{Li}, \mathrm{Ni}, \mathrm{Co}, 100 \% \\
\mathrm{Mn}, 90 \%\end{array}$ & 43 \\
\hline $\mathrm{LiFePO}_{4}$ & 0.3 & 80 & 60 & 1 & 300 & $\begin{array}{l}\mathrm{Li}, 98 \% \\
\mathrm{Fe}, 92 \%\end{array}$ & 35 \\
\hline
\end{tabular}

${ }^{a} \mathrm{Co}$ and Fe recovery weight percentages (for $\mathrm{NMC}, \mathrm{Ni}, \mathrm{Mn}$, Co metals recovery percentages) are from solid phase collected as a precipitate.

The variation in solubility of different metal oxalate species can be utilized effectively for separation of metals. ${ }^{19,20}$ Metal separation and recovery processes are commonly needed in any industry that has a mixture of metals as its primary material source. The metallurgy and recycling industries are two of the largest sectors that deal with mixed metal sources and are in need of sustainable, energy-efficient technologies for metal separation and recovery. ${ }^{21-23}$ Oxalate, which can be derived from organic sources, has minimal to no environmental effects, is generally safer to work with than typical inorganic acids and may offer the opportunity for developing a more energyefficient process. Oxalate has tremendous potential for creating an effective platform for future metals recovery and separation.

For the application of metal separation and recovery using oxalates, it is important to understand the qualitative metal oxalate solubility and possible complexes that can be formed. Hence, for any metal, the use of Figure 3, Table 1, and Table 2 can help to determine the best choice of separation based on the solubility of the simple and complex oxalates. The uniqueness of using an oxalate for separation of metals from a mixed metal source is due to the selectivity which it offers. In addition, understanding the behavior of metal mixtures in the presence of oxalate anions is necessary. This is the first comprehensive review that focuses on the applications of oxalate for metals separation and recovery from different sources. The primary applications chosen for this review article include recovery of metals from the cathode of spent lithiumion batteries, spent catalysts, ores, and waste streams.

\section{APPLICATION OF OXALATES}

2.1. Metal Recovery from the Cathode of Spent Lithium-Ion Batteries. Lithium-ion batteries (LIBs) provide power for millions of people each day. Their usage has expanded from cellular phones and laptop computers to powering hybrid and electric cars, homes, and electrical grids. The sustainability of the LIBs' life cycle depends entirely on the recycling abilities for all the components of the battery. Metals, like cobalt and nickel, which are found in the cathode of a LIB, have significant economic value. ${ }^{26}$ The cathode usually contains an oxide of lithium along with another transition metal. Common cathode materials include lithium cobalt oxide $\left(\mathrm{LiCoO}_{2}\right){ }^{11,12,27-30}$ lithium nickel cobalt oxide $\left(\mathrm{LiNi}_{x} \mathrm{Co}_{1-x} \mathrm{O}_{2}\right),{ }^{31,32}$ lithium nickel manganese cobalt oxide $\left(\mathrm{LiNi}_{0.33} \mathrm{Mn}_{0.33} \mathrm{Co}_{0.33} \mathrm{O}_{2}\right)(\mathrm{NMC}),{ }^{32-34}$ and lithium iron phos- 
phate $\left(\mathrm{LiFePO}_{4}\right){ }^{32,35,36}$ To separate metals from the cathode, strong inorganic acids like sulfuric acid, ${ }^{33,37}$ hydrochloric acid, $^{34}$ and nitric acid ${ }^{37,38}$ along with external reducing agents like $\mathrm{H}_{2} \mathrm{O}_{2}$ are used, but they have adverse environmental impacts because of emission of harmful pollutants like $\mathrm{SO}_{x}$ $\mathrm{Cl}_{2}$, and $\mathrm{NO}_{x}$. Hence, replacing an inorganic acid with an organic acid minimizes this environmental impact, making the recycling process more sustainable. A typical flowchart of the current processes is shown in Figure $4 .{ }^{39}$ In this section, the separation of valuable metals from different cathode materials using oxalates will be discussed.

For separation of $\mathrm{Li}$ and Co from LIB cathodes, oxalic acid functions as both a reducing and precipitating agent. Sohn et al. $^{28}$ compared the sulfuric acid/hydrogen peroxide leaching process with the oxalic acid leaching process. In the presence of $2 \mathrm{M}$ sulfuric acid with 10 vol\% hydrogen peroxide at $75{ }^{\circ} \mathrm{C}$ for $1.25 \mathrm{~h}$, more than $99 \mathrm{wt} \%$ of $\mathrm{Li}$ and Co were leached into the aqueous phase. Using $3 \mathrm{M}$ oxalic acid at $80^{\circ} \mathrm{C}$ for $1.5 \mathrm{~h}$ as shown in Table 3, more than $99 \mathrm{wt} \%$ of the Li leaches into the aqueous phase and $96 \mathrm{wt} \%$ of the Co precipitates out as cobalt(II) oxalate. In the sulfuric acid process, cobalt needs to be recovered separately in the form of cobalt(II) hydroxide by addition of another precipitating agent. The requirement of another precipitating agent for sulfuric acid and other inorganic/organic acids provides a unique advantage for using oxalic acid/oxalates to recover metals efficiently from the cathode of LIBs. The concentration of oxalic acid can be used to adjust the solid-to-liquid ratio to further improve the separation and process economics. Theoretically, a stoichiometric molar ratio of 2 between oxalic acid and lithium cobalt oxide should be enough to ensure complete recovery and precipitation of $\mathrm{Li}$ and $\mathrm{Co}$ respectively according to the following reaction: ${ }^{11,12,29}$

$$
\begin{aligned}
& 4 \mathrm{H}_{2} \mathrm{C}_{2} \mathrm{O}_{4}(\mathrm{aq})+2 \mathrm{LiCoO}_{2}(\mathrm{~s}) \leftrightarrows \\
& \mathrm{Li}_{2} \mathrm{C}_{2} \mathrm{O}_{4}(\mathrm{aq})+2 \mathrm{CoC}_{2} \mathrm{O}_{4} \cdot 2 \mathrm{H}_{2} \mathrm{O}(\mathrm{s})+2 \mathrm{CO}_{2}(\mathrm{aq})
\end{aligned}
$$

Zeng et al. ${ }^{11}$ used a lower concentration of acid ( $\left.1 \mathrm{M}\right)$ with a longer reaction time $(2.5 \mathrm{~h})$, higher temperature $\left(95{ }^{\circ} \mathrm{C}\right)$, higher mixing rate $(400 \mathrm{rpm})$, and lower solid-to-liquid ratio $(15 \mathrm{~g} / \mathrm{L})$. Under these conditions, $98 \mathrm{wt} \%$ of the Li leaches into the aqueous phase, and $97 \mathrm{wt} \%$ of the Co precipitates out as cobalt(II) oxalate. The addition of hydrogen peroxide was found to be insignificant in the presence of excess oxalic acid, which may be due to the oxalic acid being a better reducing agent than $\mathrm{H}_{2} \mathrm{O}_{2} \cdot{ }^{12}$ The effects of other leaching parameters such as solid-to-liquid ratio, temperature, and reaction time have also been studied. ${ }^{12,28}$ Most experiments have been run over a temperature range of $80-100{ }^{\circ} \mathrm{C}$ at atmospheric pressure. The optimum solid-to-liquid ratio for maximizing reaction rate depends on the acid concentration. For example, for an oxalic acid concentration of $1 \mathrm{M}$, the reaction rate begins to decrease above a solid-to-liquid ratio of $50 \mathrm{~g} / \mathrm{L}$. ${ }^{12}$ Aaltonen et al. ${ }^{30}$ compared citric acid, oxalic acid, sulfuric acid, hydrochloric acid, and nitric acid both in the presence and in the absence of hydrogen peroxide as a reducing agent (Table 4). The oxalic acid has both reducing and chelating properties, and the Co precipitates as cobalt(II) oxalate. The addition of hydrogen peroxide increases the leaching efficiency for all acids.

Zhang et al. $^{40}$ used oxalic acid to leach metals from $\mathrm{LiNi}_{x} \mathrm{Mn}_{y} \mathrm{Co}_{z} \mathrm{O}_{2}$ (NMC) cathodes at the conditions shown in Table 3. Under these conditions, $84 \mathrm{wt} \%$ of the Li leached into
Table 4. Summary of Experiments Performed by Aaltonen et al. ${ }^{30}$ on $\mathrm{LiCoO}_{2}{ }^{a}$

\begin{tabular}{lcc}
\multirow{2}{*}{ acid concentration } & \multicolumn{2}{c}{ metal recovery (wt\%) } \\
\cline { 2 - 3 } $2 \mathrm{M}$ citric acid & $\mathrm{no} \mathrm{H}_{2} \mathrm{O}_{2}$ & $1 \%(\mathrm{v} / \mathrm{v}) \mathrm{H}_{2} \mathrm{O}_{2}$ \\
& $\mathrm{Li}, 62 \%$ & $\mathrm{Li}, 65 \%$ \\
\multirow{2}{*}{$1 \mathrm{M}$ oxalic acid } & $\mathrm{Co}, 41 \%$ & $\mathrm{Co}, 46 \%$ \\
& $\mathrm{Li}, 74 \%$ & $\mathrm{Li}, 79 \%$ \\
$2 \mathrm{M}$ sulfuric acid & $\mathrm{Co} \mathrm{in} \mathrm{precipitate}$ & $\mathrm{Co} \mathrm{in} \mathrm{precipitate}$ \\
& $\mathrm{Li}, 88 \%$ & $\mathrm{Li}, 92 \%$ \\
$4 \mathrm{M}$ hydrochloric acid & $\mathrm{Co}, 79 \%$ & $\mathrm{Co}, 85 \%$ \\
& $\mathrm{Li}, 91 \%$ & $\mathrm{Li}, 98 \%$ \\
& $\mathrm{Co}, 85 \%$ & $\mathrm{Co}, 92 \%$ \\
& $\mathrm{Li}$ M nitric acid $85 \%$ & $\mathrm{Li}, 90 \%$ \\
& $\mathrm{Co}, 75 \%$ & $\mathrm{Co}, 83 \%$
\end{tabular}

${ }^{a}$ All experiments were carried out with a slurry density of $5 \mathrm{wt} \%$ at 25 ${ }^{\circ} \mathrm{C}$ for $24 \mathrm{~h}$.

the aqueous phase, and the transition metals ( $\mathrm{Ni}, \mathrm{Mn}, \mathrm{Co}$ ) formed oxalates that precipitated out of solution. The unreacted cathode material and oxalate precipitate were calcined with $\mathrm{Li}_{2} \mathrm{CO}_{3}$ at $900{ }^{\circ} \mathrm{C}$ for $14 \mathrm{~h}$ to regenerate the NMC cathode. In some studies, $\mathrm{Ni}$ from spent catalysts has been reported to form soluble oxalate complexes, ${ }^{41,42}$ which complicates the separation of lithium from transition metals. Therefore, the $\mathrm{pH}$ determined by the concentration of oxalic acid plays a significant role in efficient separation and leaching of metals.

Another route is to perform the metal recovery using oxalic acid generated by the fungi, $A$. niger, which has the potential to generate malic, gluconic, oxalic, and citric acids. ${ }^{43}$ Hence, the culture conditions (direct or indirect) for the growth of fungi plays a major role in determining the acid, which would be generated in the maximum amount. Horeh et al. ${ }^{43}$ found that oxalic acid was produced at higher concentration when the growth of fungi was done in the presence of cathodic material (direct process) whereas citric acid becomes the most highly produced acid in the absence of cathodic material (indirect process). The reason behind this observation could be the metals like manganese and copper acting as inhibitors for citric acid accumulation. Under the conditions of $30^{\circ} \mathrm{C}$ at $130 \mathrm{rpm}$ for 30 days, and on the addition of cathodic material from third day, $100 \mathrm{wt} \% \mathrm{Li}$ and $10 \mathrm{wt} \% \mathrm{Mn}$ leached into the aqueous phase; $100 \mathrm{wt} \% \mathrm{Ni}$ and $\mathrm{Co}$ and $90 \mathrm{wt} \% \mathrm{Mn}$ precipitated in the form of their insoluble oxalate compounds. ${ }^{43}$ Like chemical leaching, bioleaching also has an efficient separation but requires longer reaction time, which is energy intensive.

Lithium iron phosphate batteries (LIPBs) contain a $\mathrm{LiFePO}_{4}$ cathode. LIPBs pose environmental challenges due to both the hazardous electrolyte $\left(\mathrm{LiClO}_{4}\right.$ and ethylene carbonate-dimethyl carbonate) and phosphorus found in $\mathrm{LiFePO}_{4}$ that causes eutrophication of natural water. For this reason, the $\mathrm{Li}$ and $\mathrm{Fe}$ should be recovered and the phosphorus treated in an environmentally friendly process. ${ }^{35}$ Treatment of the $\mathrm{LiFePO}_{4}$ cathode with oxalate is beneficial because it can directly chelate and precipitate iron in the form of iron(II) oxalate dihydrate. However, under certain reaction conditions the presence of an oxidizing agent can oxidize insoluble iron(II) oxalate to soluble iron(III) oxalate. ${ }^{35,36,44,45}$ This reduces the advantage of the direct separation of lithium from transition metals as previously reported for $\mathrm{LiCoO}_{2}$. For $\mathrm{LiFePO}_{4}$ cathodes, the $\mathrm{Li}$ goes into the aqueous phase along with the phosphorus in the form of phosphoric acid and other 
Table 5. Examples of Metal Recovery from Spent Catalysts

\begin{tabular}{|c|c|c|c|}
\hline source & reaction conditions ${ }^{a}$ & leaching efficiency (wt\%) & ref \\
\hline spent $\mathrm{HDS}$ catalyst $\left(\mathrm{Ni}-\mathrm{Mo} / \mathrm{Al}_{2} \mathrm{O}_{3}\right)$ & $\begin{array}{l}1 \mathrm{M} \text { oxalic acid at } 40{ }^{\circ} \mathrm{C} \text { with } 300 \mathrm{rpm} \text { stirring for } 3 \mathrm{~h} \\
0.5 \mathrm{M} \text { oxalic acid and } 0.66 \mathrm{M} \mathrm{H}_{2} \mathrm{O}_{2} \text { at } 70{ }^{\circ} \mathrm{C} \text { for } 3 \mathrm{~h}\end{array}$ & $\begin{array}{l}92 \% \mathrm{Mo}, 86 \% \mathrm{Ni}, 30 \% \mathrm{Al}, 73 \% \mathrm{P} \\
63 \% \mathrm{Mo}, 80 \% \mathrm{~V}, 66 \% \mathrm{Ni}, 58 \% \mathrm{Al}\end{array}$ & $\begin{array}{l}41 \\
42\end{array}$ \\
\hline spent refinery processing catalyst & two-step bioleaching (A. niger) at $30{ }^{\circ} \mathrm{C}$ with $1 \mathrm{~g} / \mathrm{L} \mathrm{S} / \mathrm{L}$ ratio for $60 \mathrm{~d}$ & $82.3 \% \mathrm{Mo}, 58.2 \% \mathrm{Ni}$, and $54.5 \% \mathrm{Al}$ & 63 \\
\hline spent fluid catalytic cracking catalyst & two-step bioleaching $($ A. niger $)$ at $30{ }^{\circ} \mathrm{C}$ with $1 \mathrm{~g} / \mathrm{L} \mathrm{S} / \mathrm{L}$ ratio for $46 \mathrm{~d}$ & $37 \% \mathrm{~V}, 9 \% \mathrm{Ni}, 30 \% \mathrm{Al}$ & 62 \\
\hline spent hydrotreating catalyst & $\begin{array}{l}0.45 \mathrm{M} \text { oxalic acid and } 1.67 \mathrm{M} \mathrm{H}_{2} \mathrm{O}_{2} \text { at } 100{ }^{\circ} \mathrm{C} \text { for } 1 \mathrm{~h} \\
9 \mathrm{M} \mathrm{H}_{2} \mathrm{SO}_{4} \text { at } 90{ }^{\circ} \mathrm{C} \text { for } 2 \mathrm{~h}\end{array}$ & $\begin{array}{l}69.87 \% \mathrm{Mo}, 24.63 \% \mathrm{Ni} \\
99 \% \mathrm{Mo}, 98 \% \mathrm{Ni}\end{array}$ & $\begin{array}{l}57 \\
64\end{array}$ \\
\hline spent residue hydroprocessing catalyst & $1.12 \mathrm{M}$ oxalic acid at $50{ }^{\circ} \mathrm{C}$ with a solid-to-liquid ratio of $1: 40$ for $6 \mathrm{~h}$ & $97 \%$ Mo and $\mathrm{V}, 37 \% \mathrm{Ni}$ & 58 \\
\hline Pt on alumina, spent reforming catalyst & $0.3 \mathrm{M}$ oxalic acid at $80{ }^{\circ} \mathrm{C}$ with $10 \mathrm{~g} / \mathrm{L} \mathrm{S} / \mathrm{L}$ ratio for $24 \mathrm{~h}$ & $90 \% \mathrm{Pt}$, almost $100 \% \mathrm{Al}$ & 52 \\
\hline $\begin{array}{l}\text { spent desulfurization catalyst } \\
\text { (V contaminant) }\end{array}$ & $0.9 \mathrm{M}$ oxalic acid at $100{ }^{\circ} \mathrm{C}$ for $1 \mathrm{~h}$ & more than $90 \% \mathrm{~V}$ recovered & 61 \\
\hline spent vanadium catalyst & $\begin{array}{l}0.25 \mathrm{M} \text { oxalic acid at } 50{ }^{\circ} \mathrm{C} \text { with } 40 \mathrm{~g} / \mathrm{L} \mathrm{S} / \mathrm{L} \text { ratio for } 4 \mathrm{~h} \\
0.5 \mathrm{M} \text { oxalic acid and } 2 \mathrm{M} \mathrm{H}_{2} \mathrm{O}_{2} \text { at } 50{ }^{\circ} \mathrm{C} \text { with } 20 \mathrm{~g} / \mathrm{L} \mathrm{S} / \mathrm{L} \text { ratio for } 2 \mathrm{~h}\end{array}$ & $\begin{array}{l}91 \% \mathrm{~V}, 92 \% \mathrm{~K}, 63 \% \mathrm{Fe} \\
68 \% \mathrm{~V}\end{array}$ & $\begin{array}{l}53 \\
54\end{array}$ \\
\hline spent SCR denitrification catalyst & $1 \mathrm{M}$ oxalic acid at $90{ }^{\circ} \mathrm{C}$ for $3 \mathrm{~h}$ & $84 \% \mathrm{~V}, 96 \% \mathrm{Fe}$ & 45 \\
\hline
\end{tabular}

phosphate salts, which can be treated safely. The $\mathrm{Li}$ is separated using ionic sieves such as spinel-type $\mathrm{MnO}_{2}$ sieves, and calcium hydroxide is used to precipitate the phosphate ion. ${ }^{35}$ In some cases, oxalic acid was used to precipitate soluble Co from the aqueous phase when leaching with a combination of inorganic acids. ${ }^{46-49}$ In most cases, the cathode material may contain additional metals in small concentrations as well as components from the current collector that require further separation.

2.2. Recovery of Metals from Spent Catalysts. Spent catalysts are another secondary source of valuable metals that can be recovered using appropriate technology. In the petroleum refining industry, hydrodesulfurization (HDS) catalysts are widely used for removal of sulfur. HDS catalysts commonly consist of $\mathrm{Mo}, \mathrm{Ni}, \mathrm{Co}$, and $\mathrm{Al}^{41,42,50,51} \mathrm{Pt}$ - and Vbased catalysts are also valuable, and the metals need to be recovered and recycled. ${ }^{52-54}$ The metals in these catalysts can be recovered by treatment with inorganic acids such as sulfuric acid and nitric acid. ${ }^{55,56}$ For the treatment of spent catalysts, the focus has always been to leach these metals into the aqueous phase and then separate the metals from the deactivated catalyst. Oxalates, which have a high tendency to form insoluble metal oxalates in water, can precipitate transition metals on the catalyst support, which can negatively affect metal recovery. However, oxalates have shown some potential for effective leaching under appropriate conditions. This section summarizes the reaction conditions that can provide efficient leaching of the metals from spent catalysts using oxalates as summarized in Table 5.

Recovery of $\mathrm{Ni}$ and Mo using oxalic acid from spent catalysts has been demonstrated by several researchers. ${ }^{41,42,57,58} \mathrm{Ni}$ tends to form both oxalate compounds and oxalate complexes, whereas Mo forms only oxalate complexes (Figure 3 ). Ni leaching is dependent on the $\mathrm{pH}$ and oxalate concentration but is limited by the low solubility of the nickel(II) oxalate compound. The Mo leaching efficiency was more than $90 \mathrm{wt} \%$ in two different studies with oxalic acid concentrations of 1 M. ${ }^{41,58}$ However, Ni has been reported to have varying leaching efficiencies from 37 to $86 \mathrm{wt} \%$ with $1 \mathrm{M}$ oxalic acid. $^{41,88}$ The presence of other metals such as $\mathrm{V}$ and $\mathrm{Al}$, which can form complexes with oxalate, can also affect the solubility by consuming the available oxalate ions. The oxalate availability in an aqueous environment and in the presence of insoluble nickel(II) oxalate is demonstrated by the following reaction:

$$
\begin{gathered}
\mathrm{Ni}^{2+}+3 \mathrm{C}_{2} \mathrm{O}_{4}{ }^{2-} \leftrightarrows \mathrm{NiC}_{2} \mathrm{O}_{4} \cdot 2 \mathrm{H}_{2} \mathrm{O}(\mathrm{s})+2 \mathrm{C}_{2} \mathrm{O}_{4}{ }^{2-} \\
\leftrightarrows \mathrm{Ni}\left(\mathrm{C}_{2} \mathrm{O}_{4}\right)_{2}{ }^{2-}+\mathrm{C}_{2} \mathrm{O}_{4}{ }^{2-} \leftrightarrows \mathrm{Ni}\left(\mathrm{C}_{2} \mathrm{O}_{4}\right)_{3}{ }^{4-}
\end{gathered}
$$

where the solubility of insoluble nickel(II) oxalate also gets affected. Depending on the conditions, the addition of hydrogen peroxide, which has been reported to act as either an oxidizing or reducing agent, ${ }^{59,60}$ did not seem to have a significant effect on either Mo or Ni leaching efficiency. Szymczycha-Madeja ${ }^{42}$ considered the effect of adding hydrogen peroxide in the oxidation of low valence metal sulfides (e.g., HDS catalysts) to high valence metal oxides that can complex with oxalate. It should be noted that some reports have achieved $90 \mathrm{wt} \%$ leaching efficiency of Mo even without the addition of hydrogen peroxide. ${ }^{41,58}$

Vanadium is another major metal that can be found in many spent catalysts $42,45,53,54,58,61$ and is reported to form only soluble oxalates as shown in Figure 3, Table 1, and Table 2. Mazurek $^{53}$ and Erust et al. ${ }^{54}$ attempted to recover V from a spent catalyst using oxalic acid. Vanadium(IV) oxalate is formed, which is soluble in the aqueous phase. Mazurek also demonstrated the stepwise separation of $\mathrm{V}$ from a mixture containing Fe. This separation was achieved using both $\mathrm{Fe}$ precipitation and ion-exchange techniques. $\mathrm{Wu}$ et $\mathrm{al}^{45}$ reported leaching of $\mathrm{V}$ and $\mathrm{Fe}$ from denitrification catalysts. The $\mathrm{V}$ and $\mathrm{Fe}$ exist as $\mathrm{VO}^{2+}$ and $\mathrm{Fe}^{2+}$ after leaching in the aqueous phase. The vanadium(IV) oxalate is a soluble species and was expected to be present in the aqueous phase after leaching. The $\mathrm{Fe}$ was proposed to exist in the form of $\mathrm{Fe}\left(\mathrm{C}_{2} \mathrm{O}_{4}\right)_{2}{ }^{2-}$, also a soluble species. This hypothesis was confirmed by quantitatively measuring the moles of $\mathrm{CO}_{2}$ released during the redox reaction. Lee et al. ${ }^{61}$ studied the regeneration of desulfurization catalysts using $0.9 \mathrm{M}$ oxalic acid solution to leach the $\mathrm{V}$. This vanadium-rich liquor was used to synthesize dehydrogenation catalysts on silica supports, which closes the recycling loop, making this a sustainable process.

$\mathrm{Ni}, \mathrm{Mo}$, and $\mathrm{V}$ recovery from spent catalysts through bioleaching route where oxalic acid is generated by $A$. niger and fungi has also been demonstrated. ${ }^{62,63}$ Similar to the leaching of metals from cathodic material, direct leaching was found to be an optimum way which led to maximum production of oxalic acid and higher metal extraction than indirect leaching. ${ }^{62,63}$ Aung and Ting $^{62}$ suggested that the fungus participates in the leaching process through bioaccumulation of generated oxalic acid, which shifts the equilibrium toward consumption of additional oxalic acid. Other than the culture 
conditions, pulp density (solid-to-liquid ratio) also plays a major role in the growth of fungi. Higher pulp density (more than $1 \mathrm{~g} / \mathrm{L}$ ) affects the leaching efficiency because of the inability of the fungus to grow well under high concentration of heavy metals. ${ }^{62,63}$ Optimum conditions for metal extractions from spent catalysts via bioleaching from spent refinery catalysts are reported in Table 5. Reaction and fungal culture conditions play a major role in the amount of oxalic acid generated, and that has a direct impact on the leaching efficiency. Apart from longer reaction time, another difference between the bioleaching and chemical leaching is the lower solid-to-liquid ratio ( $1 \mathrm{~g} / \mathrm{L}$ to $10 \mathrm{~g} / \mathrm{L}$ (average)). This means that to extract metals from $10 \mathrm{~g}$ of spent catalyst, ten times more reaction volume is required in the case of bioleaching, and that will have a direct impact on the process economics.

2.3. Extraction of Metals from Ores. Ores are a naturally occurring source of metals usually in the form of oxides or hydroxides. Ores typically contain multiple important metals that need to be both recovered and, more importantly, separated. Similar to the spent catalyst recovery processes, inorganic acids are used to leach the metals into the aqueous phase. $^{65-68}$ However, because of the environmental hazards associated with the emission of $\mathrm{SO}_{x}$ and $\mathrm{NO}_{x}$ gases from the use of inorganic acids, research using environmentally friendly reagents like organic acids has increased. In this section, metal recovery from ores using oxalates is discussed.

Ilmenite is an iron titanate $\left(\mathrm{FeTiO}_{3}\right)$ low-grade ore mainly used for the production of titanium dioxide. Titanium dioxide is used as a white pigment in paints, plastics, and paper applications. Separation of Fe from $\mathrm{Ti}$ is the key step, and $\mathrm{Ti}$ forms a soluble oxalate complex, whereas $\mathrm{Fe}$ (II) forms an insoluble oxalate compound. Ilmenite can also contain Fe and Ti impurities such as magnetite, hematite, and rutile. Corbin et al. ${ }^{69}$ digested ilmenite using ammonium hydrogen oxalate (AHO) under different reaction atmospheres as shown in Figure 5. The titanium oxalate was soluble, whereas the

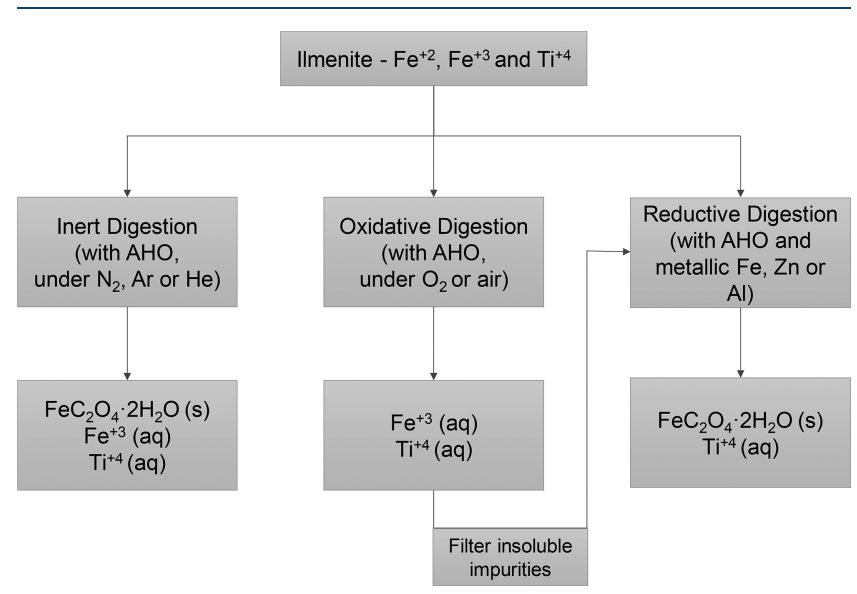

Figure 5. Summary of different digestion experiments for ilmenite (adapted from Corbin et al. ${ }^{69}$ ).

iron(II) oxalate was insoluble and formed a precipitate, providing an effective and simple separation. In the presence of an inert atmosphere such as nitrogen, helium, or argon, $\mathrm{Fe}$ (II) will not oxidize and precipitates in the form of iron(II) oxalate; however, in an oxidative atmosphere, $\mathrm{Fe}$ (II) will oxidize to $\mathrm{Fe}$ (III) that forms a soluble oxalate complex. This oxidative digestion is particularly useful for separation of impurities and unwanted materials present in the ore. Usually, oxidative digestion is followed by reduction step in an inert atmosphere, and a reducing agent like metallic $\mathrm{Fe}, \mathrm{Zn}$, or $\mathrm{Al}$ is added to reduce all the available $\mathrm{Fe}$ (III) into $\mathrm{Fe}(\mathrm{II})$ that can precipitate out of solution. The reaction atmosphere is not often considered for improving the leaching efficiency.

Corbin et al. ${ }^{69}$ developed a process to leach Ti from ilmenite and tried to completely recover the oxalate reagent as shown in the process flow diagram in Figure 6. In this case, AHO was

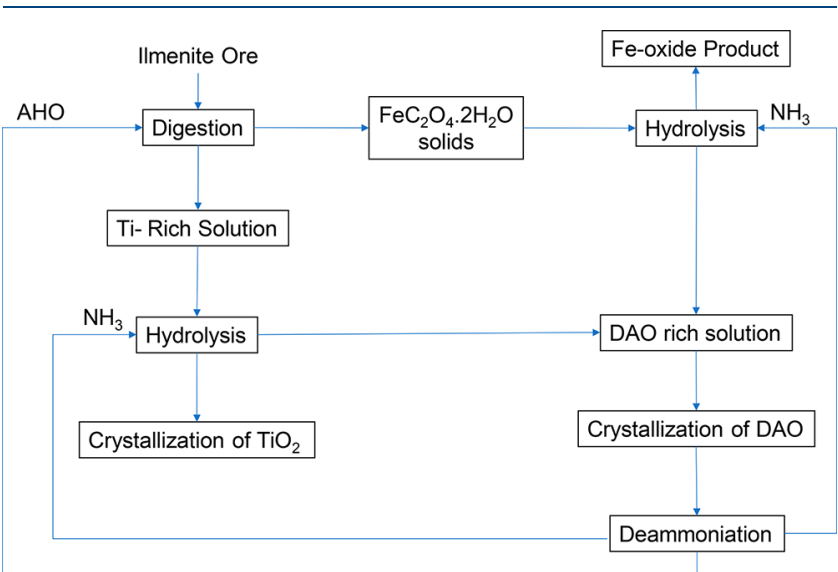

Figure 6. Simplified process flow diagram for ilmenite treatment with AHO (adapted from Corbin et al. ${ }^{69}$ ).

used for leaching $\mathrm{Ti}$ and $\mathrm{Fe}$ from ilmenite. The titanium oxalate complex goes into solution and the iron(II) oxalate species forms a precipitate, which enables the separation. Ammonia or ammonium hydroxide is used to precipitate the $\mathrm{Ti}$ out of solution by forming a titanium(IV) hydroxide that can be converted into titanium(IV) oxide. The iron(II) oxalate precipitate is reacted with ammonia or ammonium hydroxide to form diammonium oxalate (DAO) and iron(II) hydroxide that can be converted into an iron(II) oxide co-product. DAO is also produced during the Ti precipitation step and combined with DAO from the $\mathrm{Fe}$ precipitation step. The DAO is crystallized and undergoes a deammoniation step to recover AHO and $\mathrm{NH}_{3}$, which are both recycled as shown in Figure 6. ${ }^{69}$ Another closed loop process was reported by Corbin et al. ${ }^{70}$ using trimethylammonium hydrogen oxalate ((TMAH)$\left.\mathrm{HC}_{2} \mathrm{O}_{4}\right)$. The process flow diagram is shown in Figure 7. Recovery of the oxalate provides a significant advantage for the overall process economics and reduces waste streams.

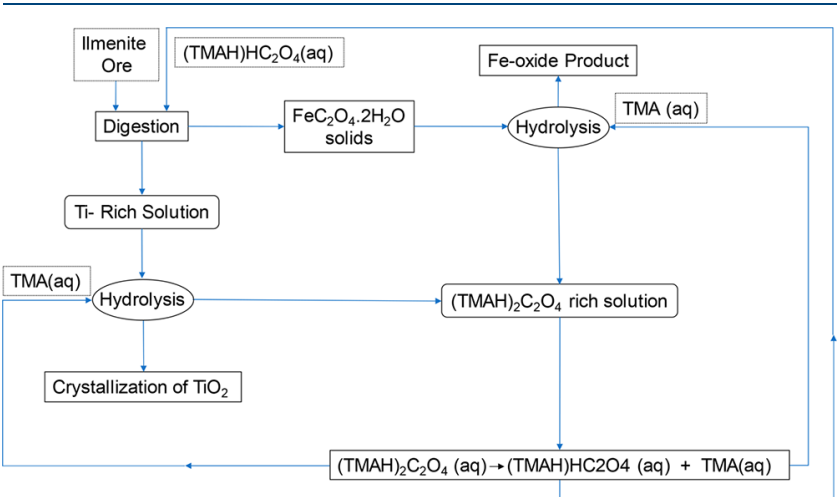

Figure 7. Simplified process flow diagram for ilmenite treatment with (TMAH) $\mathrm{HC}_{2} \mathrm{O}_{4}$ (adapted from Corbin et al. ${ }^{70}$ ). 
Table 6. Examples of Metal Extraction from Ores Using Oxalic Acid

\begin{tabular}{|c|c|c|c|}
\hline source & reaction conditions & recovery efficiency (wt\%) & ref \\
\hline \multirow[t]{2}{*}{ ilmenite } & 6.6 $\mathrm{M}$ of trimethylammonium hydrogen oxalate at $60{ }^{\circ} \mathrm{C}$ for $120 \mathrm{~h}$ & $\begin{array}{l}\mathrm{Fe} / \mathrm{Ti} \text { ratio of } 0.048 \text { compared to } 0.404 \text { in } \\
\text { starting leachate }\end{array}$ & 70 \\
\hline & $7.16 \mathrm{M}$ ammonium hydrogen oxalate at $100{ }^{\circ} \mathrm{C}$ for $72 \mathrm{~h}$ & $100 \% \mathrm{Ti}$ in leachate & 69 \\
\hline Greek laterite & $0.5 \mathrm{M}$ oxalic acid at $50{ }^{\circ} \mathrm{C}$ for 20 days & $40.30 \% \mathrm{Fe}$ and $0.71 \% \mathrm{Ni}$ in leachate & 71 \\
\hline Caldag laterite & $0.5 \mathrm{M}$ oxalic acid at $90{ }^{\circ} \mathrm{C}$ for $6 \mathrm{~h}$ & $52 \% \mathrm{Fe}$ and $20 \% \mathrm{Ni}$ and $\mathrm{Co}$ in leachate & 72 \\
\hline \multirow[t]{3}{*}{ Sukinda laterite } & $1 \mathrm{M}$ oxalic acid at $90^{\circ} \mathrm{C}$ for $40 \mathrm{~h}$ & $23 \% \mathrm{Ni}$ in leachate & 3 \\
\hline & direct bioleaching (A. humicola) at $30^{\circ} \mathrm{C}$ for 30 days with $2 \mathrm{~g} / \mathrm{L}$ solid-to-liquid ratio & $54 \% \mathrm{Ni}$ in leachate & 5 \\
\hline & $\begin{array}{l}\text { indirect bioleaching }\left(A \text {. humicola) at } 30{ }^{\circ} \mathrm{C} \text { for } 30 \text { days ( } 8 \text { days incubation) with } 2 \mathrm{~g} / \mathrm{L}\right. \\
\text { solid-to-liquid ratio }\end{array}$ & $65 \% \mathrm{Ni}$ in leachate & \\
\hline \multirow[t]{2}{*}{ low-grade $\mathrm{Mn}$ ore } & $2 \mathrm{M}$ oxalic acid at $25^{\circ} \mathrm{C}$ for 6 days with $2 \mathrm{~g} / \mathrm{L}$ solid-to-liquid ratio & $66 \% \mathrm{Mn}$ in leachate & 76 \\
\hline & $0.6 \mathrm{M}$ sulfuric acid with $0.3 \mathrm{M}$ oxalic acid at $95^{\circ} \mathrm{C}$ for $3 \mathrm{~h}$ & $99.4 \% \mathrm{Mn}, 24.3 \% \mathrm{Fe}$, and $44.6 \% \mathrm{Al}$ & \\
\hline $\begin{array}{l}\text { polymetallic Mn } \\
\text { ore }\end{array}$ & $0.5 \mathrm{M}$ sulfuric acid with $0.24 \mathrm{M}$ oxalic acid at $85^{\circ} \mathrm{C}$ for $1.75 \mathrm{~h}$ & $98 \% \mathrm{Mn}, 94 \% \mathrm{Zn}$, and $92 \% \mathrm{Cu}$ & \\
\hline scheelite & $1 \mathrm{M}$ oxalic acid at $55^{\circ} \mathrm{C}$ for $3 \mathrm{~h}$ & $99 \% \mathrm{~W}$ in leachate & \\
\hline
\end{tabular}

Another iron-based ore is laterite. Laterites are a source of $\mathrm{Fe}$ and $\mathrm{Ni}$ present in the form of their oxides. As discussed in section 2.2, $\mathrm{Ni}$ forms both oxalate compounds and oxalate complexes, which can limit the ability to separate it using oxalates. Similarly, Fe can also form both soluble iron(III) oxalate complexes and insoluble iron(II) oxalate. Tzeferis and Agatzini-Leonardou, ${ }^{71}$ Kursunoglu and Kaya, ${ }^{72}$ and Sahu et al. $^{73}$ have used oxalic acid to leach metals from laterites collected from different parts of the world. Tzeferis and Agatzini-Leonardou tested the ability of oxalic acid to solubilize $\mathrm{Ni}$ and $\mathrm{Fe}$ from Greek laterite ores. Under their reaction conditions, $\mathrm{Ni}$ formed an insoluble nickel(II) oxalate, and $40.3 \mathrm{wt} \%$ of the Fe leached into the aqueous phase. Oxalic acid reduced $\mathrm{Fe}$ (III) to $\mathrm{Fe}(\mathrm{II})$, and it was claimed that iron(II) oxalate was soluble in the aqueous phase. However, this contradicts the solubility reported in the previous studies. ${ }^{18,74}$ Iron(III) oxalate is the soluble species, and iron(II) oxalate is insoluble. A possible explanation is the formation of an oxalate complex of iron(II) in an aqueous environment as shown in eq 4:

$$
\begin{gathered}
\mathrm{Fe}^{2+}+3 \mathrm{C}_{2} \mathrm{O}_{4}{ }^{2-} \leftrightarrows \mathrm{FeC}_{2} \mathrm{O}_{4} \cdot 2 \mathrm{H}_{2} \mathrm{O}(\mathrm{s})+2 \mathrm{C}_{2} \mathrm{O}_{4}{ }^{2-} \\
\leftrightarrows \mathrm{Fe}\left(\mathrm{C}_{2} \mathrm{O}_{4}\right)_{2}{ }^{2-}+\mathrm{C}_{2} \mathrm{O}_{4}{ }^{2-} \leftrightarrows \mathrm{Fe}\left(\mathrm{C}_{2} \mathrm{O}_{4}\right)_{3}{ }^{4-}
\end{gathered}
$$

Kursunoglu and $\mathrm{Kaya}^{72}$ reported $52 \mathrm{wt} \%$ leaching of $\mathrm{Fe}$ from Caldag laterite ore. In this example, oxidation state of $\mathrm{Fe}$ in leachate was not determined. If reduction of $\mathrm{Fe}$ (III) was achieved, it would probably form additional complexes under the specified reaction conditions. Another possibility could be the incomplete reduction of $\mathrm{Fe}$ (III) using oxalic acid that could lead to a mixture of iron(III) oxalate and iron(II) oxalate. Iron(III) oxalate will remain in the aqueous phase and can be detected using atomic absorption spectroscopy (AAS) or inductively coupled plasma-atomic emission spectroscopy (ICP-AES). Another important difference between the two processes was the reaction temperature and time. Greek laterite required 20 days at $50{ }^{\circ} \mathrm{C}$ and Caldag laterite required $6 \mathrm{~h}$ at $90{ }^{\circ} \mathrm{C}$ to achieve equal weight percentages of iron dissolution. Although the reaction temperature is higher, the geographical location where ore is mined plays a significant role in the leaching efficiency. In general, the more an ore is weathered (i.e., oxidized) the longer the reaction time. Sahu et al. ${ }^{73}$ worked with Sukinda laterite and found that $23 \mathrm{wt} \% \mathrm{Ni}$ was leached into the aqueous phase under the conditions reported in Table 6. Bioleaching of Ni from Sukinda laterite using Aspergillus humicola SKP102 was demonstrated by
Ghosh and Paul. ${ }^{75}$ In their work, 54\% $\mathrm{Ni}$ was leached in direct one-step leaching (ore and fungus together from starting), whereas indirect leaching (fungi was first incubated for 8 days, followed by addition of ore) led to $65 \% \mathrm{Ni}$ leaching into the aqueous phase. Higher leaching efficiency for indirect leaching was attributed to the reduced interaction between fungi and heavy metals. ${ }^{75}$ This trend in result is contradictory to the observations by Aung and Ting for Ni leaching from spent catalysts. Possibly both of the factors, amount of oxalic acid generated and interaction between heavy metals and fungi, play determining roles in the extraction of metals.

Das et al. ${ }^{76}$ and Sahoo et al. ${ }^{77}$ attempted to recover Mn from low-grade manganese ores. Manganese also forms both oxalate compounds and complexes similar to $\mathrm{Fe}$ and $\mathrm{Ni}$. Both ores were extracted from the Keonjhar region in Orissa, India. In these ores, $\mathrm{Mn}$ is present in the form of manganese(IV) dioxide. Das et al. ${ }^{76}$ recovered 66 wt $\%$ of $\mathrm{Mn}$ in 6 days by using a $2 \mathrm{M}$ oxalic acid concentration at a very dilute solid-to-liquid ratio $\left(0.02 \mathrm{~kg} / \mathrm{m}^{3}\right)$ and $25{ }^{\circ} \mathrm{C}$. The $\mathrm{Mn}(\mathrm{IV})$ was reduced to $\mathrm{Mn}$ (II) and formed an insoluble oxalate compound. Significant improvement in the leaching efficiency was demonstrated by Sahoo et al. ${ }^{77}$ by using a mixture of sulfuric acid and oxalic acid as the leaching agent. The mixed acid recovered almost $99 \mathrm{wt} \%$ of the Mn from these ores. The manganese(II) oxalate formed a precipitate layer on the ore, and the reaction was proposed to follow the diffusion through product layer model. Azizi et al. ${ }^{78}$ studied the kinetics and developed models for optimizing the leaching process for low-grade manganese ores. A series of experiments were carried out to determine the optimum operating conditions for $\mathrm{Mn}$ and Fe recovery as a function of the amount of sulfuric acid, the amount of oxalic acid, temperature, and time. Under optimum conditions, $93.4 \mathrm{wt} \%$ $\mathrm{Mn}$ and $15.8 \mathrm{wt} \% \mathrm{Fe}$ can be leached using $0.7 \mathrm{M}$ sulfuric acid and $0.5 \mathrm{M}$ oxalic acid for $1 \mathrm{~h}$ at $63{ }^{\circ} \mathrm{C}$. Hazek et al. ${ }^{79}$ performed a similar study as Sahoo et al. ${ }^{77}$ on a polymetallic $\mathrm{Mn}$ ore and leached $98 \mathrm{wt} \% \mathrm{Mn}, 94 \mathrm{wt} \% \mathrm{Zn}$, and $92 \mathrm{wt} \% \mathrm{Cu}$ using the optimum conditions for sulfuric acid leaching with oxalic acid as a reductant. These studies prove that the addition of sulfuric acid can improve the leaching efficiency for $\mathrm{Mn}$.

Scheelite is a calcium tungsten ore with the chemical formula $\mathrm{CaWO}_{4}$. In work by Kalpakli et al. ${ }^{80}$ synthetically prepared $\mathrm{CaWO}_{4}$ was dissolved in oxalic acid. This dissolution took place in two steps. In the first step, a calcium aqua oxalate tungstate intermediate $\left(\mathrm{Ca}\left[\mathrm{WO}_{3}\left(\mathrm{C}_{2} \mathrm{O}_{4}\right) \mathrm{H}_{2} \mathrm{O}\right]\right)$ was formed. In the second step, a water-soluble hydrogen aqua oxalate tungstate $\left(\mathrm{H}_{2}\left[\mathrm{WO}_{3}\left(\mathrm{C}_{2} \mathrm{O}_{4}\right) \mathrm{H}_{2} \mathrm{O}\right]\right)$ and insoluble calcium(II) 
oxalate were formed. The proposed mechanism was based on a theoretical equilibrium calculation. In the method by Osthoff, ${ }^{81}$ scheelite ore was first treated with an aqueous solution of oxalic acid, which led to the formation of soluble tungstic acid $\left(\mathrm{H}_{2} \mathrm{WO}_{4}\right)$ and insoluble calcium oxalate. Ammonium hydroxide was added to precipitate tungsten in the form of ammonium paratungstate. Davey ${ }^{82}$ found another process to extract tungsten from scheelite using hydrochloric acid and oxalic acid where tungsten goes into the solution and, via hydrolysis, is precipitated. According to Figure 3, W forms only oxalate complexes, which leads to efficient leaching.

2.4. Recovery of Metals from Waste Streams. In this section, the recovery of precious metals from different kinds of waste streams will be discussed. These waste streams contain important metals such as $\mathrm{Co}, \mathrm{Ni}$, and $\mathrm{Fe}$.

Alumina extraction from bauxite produces a waste commonly referred to as "red mud" that contains primarily iron(III) oxide. Yang et al. ${ }^{83}$ proposed using oxalic acid to leach $\mathrm{Fe}$ (III) in the form of $\mathrm{Fe}\left(\mathrm{C}_{2} \mathrm{O}_{4}\right)_{3}{ }^{3-}$ into the aqueous phase. To separate the ferric ions from the leachate, metallic $\mathrm{Fe}$ was added to reduce and precipitate iron(II) oxalate. The observation of oxalic acid acting only as a chelating agent and not as a reducing agent contradicts other reports in the literature. ${ }^{14,15,84}$ The occurrence of a combined reduction and complexation to form a soluble species such as $\mathrm{Fe}\left(\mathrm{C}_{2} \mathrm{O}_{4}\right)_{2}{ }^{2-}$ is another possibility that should be studied. Vakilchap et al. ${ }^{85}$ studied leaching of red mud using organic acids excreted by $A$. niger and found out that, under a direct one-step leaching process, $69.8 \% \mathrm{Al}, 60 \% \mathrm{Ti}$, and $25.4 \% \mathrm{Fe}$ were leached into the aqueous phase. In the case of bioleaching of red mud, the combined effect of all the acids excreted over the whole incubation period (citric, oxalic, gluconic) plays a major role in metal leaching although the formation of insoluble iron(II) oxalate could be the reason behind the low leaching efficiency observed for Fe. ${ }^{85}$

Electroless plating is a non-galvanic process wherein a metal is deposited on a surface without the use of external electrical power and generates an aqueous waste containing metals. Gyliene et al. ${ }^{86,87}$ demonstrated the recovery of $\mathrm{Ni}, \mathrm{Cu}$, and $\mathrm{Co}$ from plating solutions using oxalic acid under specific $\mathrm{pH}$ conditions to recover more than $90 \mathrm{wt} \%$ of the metals in the form of insoluble metal oxalates (Table 7). It is important to understand the role that $\mathrm{pH}$ can play in the solubility of any

Table 7. Examples of Extraction of Metals from Waste Streams

\begin{tabular}{|c|c|c|c|}
\hline source & reaction conditions & $\begin{array}{l}\text { recovery efficiency } \\
\text { (wt } \%)\end{array}$ & ref \\
\hline \multirow[t]{3}{*}{ red mud } & $\begin{array}{l}\text { 1:1 ratio of oxalic acid with red } \\
\text { mud was used at } 95{ }^{\circ} \mathrm{C} \text { for } 1.5 \mathrm{~h}\end{array}$ & $\begin{array}{l}94.15 \% \mathrm{Fe} \text { and } \\
21.12 \% \mathrm{Al}\end{array}$ & 83 \\
\hline & $\begin{array}{l}\text { A. niger at } 30{ }^{\circ} \mathrm{C} \text { for } 30 \text { days with } \\
2 \mathrm{~g} / \mathrm{L} \text { solid-to-liquid ratio }\end{array}$ & $\begin{array}{l}69.8 \% \mathrm{Al}, 60 \% \mathrm{Ti} \\
\text { and } 25.4 \% \mathrm{Fe}\end{array}$ & 85 \\
\hline & $\begin{array}{l}3 \mathrm{M} \mathrm{H}_{2} \mathrm{SO}_{4} \text { at } 60^{\circ} \mathrm{C} \text { with } 5 \mathrm{~g} / \mathrm{L} \\
\text { solid-to-liquid ratio for } 4 \mathrm{~h}\end{array}$ & $\begin{array}{l}37 \% \mathrm{Al}, 64.5 \% \mathrm{Ti} \\
\text { and } 46 \% \mathrm{Fe}\end{array}$ & 93 \\
\hline $\begin{array}{l}\text { spent electro- } \\
\text { less plating } \\
\text { solution }\end{array}$ & $0.3 \mathrm{M}$ oxalic acid at $25^{\circ} \mathrm{C}$ at $\mathrm{pH} 9$ & $\begin{array}{l}99 \% \mathrm{Ni} \text { and } \mathrm{Co} \\
90 \% \mathrm{Cu}\end{array}$ & 86 \\
\hline $\begin{array}{l}\text { galvanic solu- } \\
\text { tion }\end{array}$ & $\begin{array}{l}\text { selective precipitation at different } \\
\mathrm{pH} \text { using oxalic acid }\end{array}$ & $\begin{array}{l}>95 \% \text { recovery of } \\
\quad \mathrm{Cu}, \mathrm{Ni}, \mathrm{Co}, \mathrm{Sn}\end{array}$ & 87 \\
\hline $\begin{array}{l}\text { CCA, treated } \\
\text { pinewood }\end{array}$ & $\begin{array}{l}20 \mathrm{~mL} \text { mixture of acetic and oxalic } \\
\text { acids with } 1 \mathrm{~g} \text { of wood at } 160^{\circ} \mathrm{C} \\
\text { for } 0.5 \mathrm{~h}\end{array}$ & $\begin{array}{l}98 \% \mathrm{As}, 99 \% \mathrm{Cr} \\
\text { and } 34 \% \mathrm{Cu} \text { in } \\
\text { leachate }\end{array}$ & 92 \\
\hline $\begin{array}{l}\text { zinc pickling } \\
\text { solution }\end{array}$ & $\begin{array}{l}\text { tributyl phosphate for leaching and } \\
1 \mathrm{M} \text { oxalic acid for precipitation } \\
\text { at } 25{ }^{\circ} \mathrm{C}\end{array}$ & $95 \% \mathrm{Zn}$ & 88 \\
\hline
\end{tabular}

metal oxalate species. Pickling liquor is another waste generated by the plating industry that contains mainly $\mathrm{Zn}$. Oxalate can be effective for recovery of $\mathrm{Zn}$ from pickling liquor waste because of the formation of insoluble zinc(II) oxalate that can be easily separated. ${ }^{88}$

Chromate copper arsenate (CCA) treatment is still used to preserve timber and extend the life of wood-based products. There is a threat to the environment due to toxic As and $\mathrm{Cr}$ leaching from the wood. In addition, burning the wood releases toxic smoke. Yu et al. ${ }^{89}$ demonstrated the possibility of using oxalic acid for the extraction of As and $\mathrm{Cr}$ but found it to be ineffective for $\mathrm{Cu}$. Arsenic and chromium have been reported to form soluble oxalate species, confirming the effectiveness of oxalic acid in the extraction process. ${ }^{18,90,91}$ To effectively extract all three metals from wood, a two-step acid treatment using oxalic and acetic acids was attempted by Shupe et $\mathrm{al}^{92}$ However, even in this process, $\mathrm{Cu}$ extraction was limited by the formation of insoluble copper(II) oxalate, which led to only $34 \mathrm{wt} \%$ recovery (Table 7 ).

2.5. Purification and Decontamination. There are a variety of minerals that contain metal impurities that impact their use for certain applications; therefore, it is important to purify these minerals and recover the unwanted but precious metals. Using an organic reagent like oxalic acid for the removal of these metals can provide a clean and green process for this purpose. In the following section, purification of silicabased minerals and removal of toxic metals from soil are discussed.

2.5.1. Removal of Iron Oxides from Silica-Based Materials. The dissolution of iron oxides using oxalic acid is an important process in several fields such as the removal of oxides from metal surfaces and the beneficiation of minerals such pottery stone and clays. Clays like kaolin are usually contaminated with $\mathrm{Fe}$ (II) and $\mathrm{Fe}$ (III) ions that directly affect the whiteness of the ceramics formed from them. ${ }^{94,95}$ Inorganic acids are considered to be unsuitable for removal of metals because of additional contamination and environmental pollution associated with sulfate and chloride ions. ${ }^{96,97}$ Dissolution of iron oxide using oxalic acid has been extensively studied by many researchers. In this section, a few references are provided for understanding the dissolution mechanism, and applications will also be discussed. Baumgratner et al., ${ }^{98}$ Panias et al., ${ }^{13,14}$ and Taxiarchou et al. ${ }^{15}$ have studied the dissolution of pure iron oxides and established a mechanism that has been verified by Veglio et al., ${ }^{96,97}$ Lee et al., ${ }^{84,99,100}$ and Ubaldini et al. ${ }^{101}$ Panias et al. ${ }^{13}$ describes a three-step dissolution mechanism: (1) adsorption of organic ligands on the iron oxide surface, (2) non-reductive dissolution, and (3) reductive dissolution. Non-reductive dissolution is a simple desorption process that can remove only the most reactive sites from the oxide surface. The reductive dissolution involves reduction of $\mathrm{Fe}(\mathrm{III})$ to $\mathrm{Fe}(\mathrm{II})$ that involves a slow induction period followed by a fast dissolution via an autocatalytic mechanism. Factors such as $\mathrm{pH}$ of the initial solution, temperature, and presence of UV light can affect the dissolution. Panias et al. ${ }^{14}$ also studied the autocatalytic effect exclusively for hematite dissolution in oxalic acid by addition of $\mathrm{Fe}$ (II) at the beginning of the reaction. This reduced the induction time for reductive dissolution and increased the rate for the autocatalytic reaction. Taxiarchou et al. ${ }^{15}$ carried out the hematite dissolution in an inert atmosphere under visible light and found that the dissolution proceeded much faster. In the absence of visible light under an oxidizing atmosphere, the induction time was 
much longer and the photocatalytic reduction decreased. Another important point to note here is that although iron(II) oxalate $\left(\mathrm{FeC}_{2} \mathrm{O}_{4} \cdot 2 \mathrm{H}_{2} \mathrm{O}\right)$ is an insoluble compound, its solubility increases at higher $\mathrm{pH}$, forming $\mathrm{Fe}\left(\mathrm{C}_{2} \mathrm{O}_{4}\right)_{2}{ }^{2-}$ and $\mathrm{Fe}\left(\mathrm{C}_{2} \mathrm{O}_{4}\right)_{3}{ }^{3-}$.

Vegliò et al. ${ }^{96,97}$ studied the Fe removal process from quartz, an essential raw material for ceramics, paper making, and highvalue products such as optical fibers. For optical fiber production, the $\mathrm{Fe}$ content in the quartz should be less than $10 \mathrm{~g} /$ tonne; however, the Fe content is normally around $77 \mathrm{~g} /$ tonne in regular quartz. Quartz from two different sources was leached with oxalic acid and a mixture of oxalic acid and sulfuric acid, as shown in Table $8 .^{96,97}$ Using only oxalic acid,

Table 8. Summary of Iron Oxide Dissolution from Quartz Using Oxalates

\begin{tabular}{lccc} 
source & \multicolumn{1}{c}{ reaction conditions } & $\begin{array}{c}\text { Fe extraction } \\
(\mathrm{wt} \%)\end{array}$ & ref \\
quartz & $\begin{array}{c}3 \mathrm{~g} / \mathrm{L} \text { oxalic acid with } 10 \% \text { solid-to-liquid } \\
\text { ratio at } 80{ }^{\circ} \mathrm{C} \text { for } 3 \mathrm{~h}\end{array}$ & $98-100 \%$ & 97 \\
& $\begin{array}{l}2 \mathrm{~kg} / \mathrm{t} \text { sulfuric acid and } 3 \mathrm{~kg} / \mathrm{t} \text { oxalic acid at } \\
90^{\circ} \mathrm{C} \text { for } 5 \mathrm{~h}\end{array}$ & $35-45 \%$ & 96 \\
& & & \\
\end{tabular}

roughly $98-100 \mathrm{wt} \%$ of the Fe was extracted, whereas in the presence of the oxalic and sulfuric acids mixture only 35-45 wt $\%$ of the Fe could be extracted. This extreme difference in the $\mathrm{Fe}$ recovery was due to the presence of $52 \mathrm{wt} \%$ iron in the micaceous fraction for the quartz used in the combined acid process. The $\mathrm{Fe}$ content from the micaceous fraction is extremely difficult to remove. In addition, in the oxalic acid experiment the ore was ground to an average particle size of about $20 \mu \mathrm{m}$ that provides additional surface area and improves the dissolution process. This comparison also emphasizes the importance of geographical location for minerals used in the metal leaching process as discussed in section 2.3 .

Lee et al. studied iron oxide removal from clay ${ }^{84}$ and dissolution of iron oxide ${ }^{100}$ using oxalic acid. The nonhematite iron oxides dissolved faster than the hematite, confirming the mechanism reported earlier. In this study, grinding was performed to decrease the average particle diameter to $150 \mu \mathrm{m}$. Although the particle size was larger than the previous study with quartz, ${ }^{97}$ higher oxalic acid concentrations of $0.19 \mathrm{M}$ at $100{ }^{\circ} \mathrm{C}$ for $2 \mathrm{~h}$ led to $90 \mathrm{wt} \%$ $\mathrm{Fe}$ removal from clay. In this case, the $\mathrm{pH}$ of the solution was reported to be 1.23 . As discussed previously, dissolution of iron oxide is controlled primarily by $\mathrm{pH}$, temperature, and oxalate concentration. Lee et $\mathrm{al}^{84}$ used ammonium hydroxide to control the $\mathrm{pH}$ in the range of 2.5-3.0 for optimizing the reaction rate for hematite and iron oxide rust. Iron extraction efficiency from both of these materials reached a maximum at a
$\mathrm{pH}$ of about 2.5. This behavior is attributed to the predominant oxalate species being $\mathrm{HC}_{2} \mathrm{O}_{4}{ }^{-}$in the $\mathrm{pH}$ range of 2.5-3.0 (see Figure 2). This is responsible for the reduction of $\mathrm{Fe}$ (III) to $\mathrm{Fe}$ (II).

2.5.2. Removal of Toxic Metals from Soil. Soil contamination with potentially toxic heavy metals like $\mathrm{As}, \mathrm{Pb}, \mathrm{Cd}$, and $\mathrm{Zn}$ is common around the world. This is more predominant in developing countries where there has been a sudden increase in activities such as mining due to increasing industrialization. Soil can be decontaminated by ex situ washing using acids, surfactants, and chelating agents. Chelating agents such as ethylenediaminetetraacetic acid (EDTA) and ethylenediamine$N, N^{\prime}$-disuccinic acid (EDDS) form stable complexes with heavy metals over a broad $\mathrm{pH}$ range but have adverse health effects on humans. ${ }^{102}$ On the other hand, strong acids like hydrochloric acid and sulfuric acid degrade the soil structure. Therefore, organic acids such as oxalic acid, which are milder and have metal complexing and dissolution properties, can be used to remove toxic metals from contaminated soil.

The composition of toxic metals in the soil varies depending on the source of the industrial pollutants that contaminate the soil. The variation in the extraction of toxic metals like $\mathrm{Cd}$ from different soils is shown in Table 9. An interesting observation is the inability of oxalic acid to leach $\mathrm{Cu}$ (II) and $\mathrm{Pb}$ (II). For example, oxalic acid was more effective than citric and acetic acids at leaching As from soil samples collected in the vicinity of a lead battery plant in the Czech Republic, but it was ineffective at extracting $\mathrm{Pb} .^{91}$ The ineffectiveness of oxalic acid to remove $\mathrm{Cu}$ and $\mathrm{Pb}$ may have more to do with the extremely low solubility of these metal oxalates compared to other heavy metals. ${ }^{94}$ Their tendency to form oxalate complexes is mentioned in Figure 3, but the extremely low leaching into the aqueous phase suggests that the oxalate complexes of $\mathrm{Pb}$ and $\mathrm{Cu}$ are not easily formed.

In general, the extraction of heavy metals from contaminated soil using oxalates is affected by several factors. A major factor is the presence of $\mathrm{Ca}$ and $\mathrm{Na}$ ions in the soil that form extremely stable complexes with oxalic acid reducing the oxalate available to complex with other metals of interest. Also, the variability of soils from one region to the next can make an effective decontamination process difficult to control. The form of the heavy metals is another factor that controls the efficiency for any extractant. Arsenic occurs in the form of a residual fraction (O-As: oxygen bound arsenic) that is the most stable fraction and in the form of $\mathrm{Fe}-\mathrm{As}$ ( $\mathrm{Fe}$ bound), $\mathrm{Al}-\mathrm{As}$ ( $\mathrm{Al}$ bound), and $\mathrm{Ca}-\mathrm{As}$ ( $\mathrm{Ca}$ bound) which are intertransformed fractions. These inter-transformed fractions have limited mobility, and it is difficult for a mild acid like oxalic acid to extract As. Also, for Cd the adsorbed fraction (exchangeable fraction) in soil is the most active, followed by iron/manganese oxyhydroxides bound, organic matter

Table 9. Summary of Soil Decontamination Using Different Techniques

\begin{tabular}{|c|c|c|c|}
\hline source of soil & leaching procedure & metal extraction (wt\%) & ref \\
\hline $\begin{array}{l}\text { zinc-lead smelting plant } \\
\text { (Iran) }\end{array}$ & 12 step washing with $0.01 \mathrm{M}$ oxalic acid & $34.3 \% \mathrm{Zn}, 2.4 \% \mathrm{Cd}, 0 \% \mathrm{Cu}$ & 103 \\
\hline sandy loam soil & $20 \mathrm{mmol} / \mathrm{kg}$ oxalic acid for $24 \mathrm{~h}$ & $\begin{array}{l}40 \% \mathrm{Cd}, 15 \% \mathrm{Cu}, 5 \% \mathrm{Mn}, 35 \% \mathrm{Ni}, 3 \% \mathrm{~Pb} \\
10 \% \mathrm{Zn}\end{array}$ & 104 \\
\hline $\begin{array}{l}\text { surface soil near mining area } \\
\text { (China) }\end{array}$ & $\begin{array}{l}0.05 \mathrm{M} \text { phosphoric acid, } 0.075 \mathrm{M} \mathrm{Na}_{2} \mathrm{EDTA}, 0.075 \mathrm{M} \text { oxalic acid in sequence } \\
\text { for } 0.5 \mathrm{~h} \text { per step }\end{array}$ & $41.9 \%$ As, $89.6 \%$ Cd & 90 \\
\hline \multirow{2}{*}{$\begin{array}{l}\text { brass smelter plant } \\
\text { (Switzerland) }\end{array}$} & $0.4 \mathrm{M} \mathrm{Na}_{2}$ EDTA at $\mathrm{pH} 7$ for $24 \mathrm{~h}$ & $17 \% \mathrm{Zn}, 29 \% \mathrm{Cu}$ & 105 \\
\hline & $0.4 \mathrm{M}$ EDDS at $\mathrm{pH} 7$ for $24 \mathrm{~h}$ & $19 \% \mathrm{Zn}, 53 \% \mathrm{Cu}$ & 105 \\
\hline
\end{tabular}


bound, and sulfides bound. For these different forms, $\mathrm{pH}$ and atmospheric conditions can lead to difficulty and variability in extraction. $^{90,91}$

\section{SAFETY HAZARDS}

Oxalates are considered to be potentially toxic and have caused accidental deaths. ${ }^{106}$ Interestingly, oxalic acid was the poison chosen for the first experimental toxicology study published in 1823. ${ }^{107}$ Oxalate concentration inside the human body increases mainly because of the consumption of food like rhubarb, star fruit, and sorrel, which have been cited as the major sources of oxalates. ${ }^{108,109}$ Oxalates in the human body can be present in the form of calcium oxalate crystals, ionic, and nanocrystal forms. Except for calcium oxalate crystals, the other forms are readily absorbed by the human body and are reported to have harmful effects such as loss of calcium and electrolyte imbalances, alteration of breast cells to tumor cells, and damage to nerve structures. Finally, the major cause of kidney stones is due to the formation of calcium(II) oxalate monohydrate and dihydrate crystals. ${ }^{110,111}$ The toxicity limit for humans is about $4-5 \mathrm{~g}$ of oxalic acid, which is due to the low excretion rate of $20 \mathrm{mg}$ per day. ${ }^{109}$

Oxalic acid also has a local caustic effect. Absorptive poisoning occurs through the skin and mucous membranes. Oral ingestion, which is a rare occurrence in the chemical industry, can lead to acute irritation and pain in the mouth and stomach. It has also been reported that workers who had contact with $5 \mathrm{wt} \%$ oxalic acid without protective gloves complained about severe pain in their hands after a few days. Inhalation of oxalate dust or vapors from a solution can cause headaches, anxiousness, and rashes. Long-term exposure can lead to skin rashes and brittle yellow fingernails. ${ }^{7,112}$

A high level of safety is required with two particular oxalates: mercury oxalate and silver oxalate. These oxalates are reported to be explosive by the U.S. government in the 2017 annual list of explosive materials. ${ }^{113}$ The first incident involving mercury happened in 1860 when an explosion occurred after Hart ${ }^{114}$ left some mercury(II) oxalate drying overnight. The explosion was so violent that the glass basin used for drying was destroyed and only a few small pieces were found. ${ }^{114}$ The theoretical explosive pressures for mercury(II) oxalate and silver oxalate are reported to be $\frac{300 \mathrm{~atm}}{n}$ and $\frac{712 \mathrm{~atm}}{n-0.06}$, respectively, where $n$ is the number of moles of explosive present. ${ }^{115}$ According to the theoretical data, these oxalates are not as explosive as TNT (trinitrotoluene), RDX (hexogen), and HMX (octogen), but they pose a potential safety hazard, and severe precautions are required.

\section{CONCLUSIONS}

Efficient metal recovery and separation are essential for both improving sustainability and reducing environmental impacts for any process that involves critical and precious metals. This article has summarized the literature for a variety of relevant metal oxalate processes from various fields. Oxalates are known for chelating metals, and this can be exploited for the dissolution and separation of metals. In addition, oxalic acid derivatives such as ammonium hydrogen oxalate can also be used as leaching agents that may also provide an economical means to recycle and recover the oxalate.

For separation of $\mathrm{Li}$ and $\mathrm{Co}$ in spent lithium-ion battery cathodes, oxalate has shown excellent selectivity in precipitating most of the Co. Other metal-oxalate complexes for which selectivity via precipitation has been demonstrated include $\mathrm{Ni}$ and $\mathrm{Fe}(\mathrm{II})$. For $\mathrm{Mo}, \mathrm{W}$, and V, the formation of metal oxalate complexes has shown efficient leaching of these metals into the aqueous phase. Interaction of $\mathrm{Fe}$ with oxalates is one of the most interesting and studied chemistries, with the possibility of soluble iron(III) oxalate, insoluble iron(II) oxalate, and various oxalate complexes. Reaction conditions (temperature, $\mathrm{pH}$, and time) also play a significant role in whether Fe will end up in the aqueous or solid phase.

Apart from reaction conditions, reaction atmosphere is another variable that can be varied to obtain desired results particularly in the case of $\mathrm{Fe}$ where the solubility of the metal oxalate complexes depends on the metal oxidation states. Under an oxidative atmosphere, higher oxidation state species become predominant, whereas under an inert atmosphere or reductive atmosphere lower oxidation state metal species are predominant. Leaching can also be improved by mixing oxalic acid with other inorganic acids. This can lead to a significant increase in acidity that results in better leaching. This needs to be done carefully because a decrease in $\mathrm{pH}$ will also affect the complexing capability of oxalic acid. For a $\mathrm{pH}$ lower than 1.23, the $\mathrm{H}_{2} \mathrm{C}_{2} \mathrm{O}_{4}$ species is predominant (see Figure 2), and for complexation ionic oxalates $\left(\mathrm{HC}_{2} \mathrm{O}_{4}{ }^{-}\right.$and $\left.\mathrm{C}_{2} \mathrm{O}_{4}{ }^{2-}\right)$ are required.

Oxalic acid is more expensive than other inorganic acids such as sulfuric or hydrochloric acid. If the metal has a high selling price, this cost difference can be overcome. In addition, methods for recovery and recycling of oxalate can further reduce the cost. There has been little focus on the recovery of oxalates, which provides future research opportunities. Along with the improvement in oxalate chemistry for metal recovery and separation, the major challenge will be to improve the economics so that clean, green, and sustainable metal recovery and separation processes can be developed in the future.

\section{AUTHOR INFORMATION}

\section{Corresponding Author}

*E-mail: mark.b.shiflett@ku.edu.

ORCID ○

Ankit Verma: 0000-0003-2244-5134

Rajkumar Kore: 0000-0002-3361-1188

Mark B. Shiflett: 0000-0002-8934-6192

\section{Notes}

The authors declare no competing financial interest.

\section{REFERENCES}

(1) Sawada, H.; Murakami, T. Oxalic Acid. Kirk-Othmer Encyclopedia of Chemical Technology; Wiley: New York, 2000.

(2) Krishnamurty, K. V.; Harris, G. M. The Chemistry of the Metal Oxalato Complexes. Chem. Rev. 1961, 61 (3), 213-246.

(3) Cleland, W. W.; Johnson, M. J. Studies on the Formation of Oxalic Acid by Aspergillus Niger. J. Biol. Chem. 1956, 220 (2), 595606.

(4) Kondô, K.; Ameyama, M. Carbohydrate Metabolism by Acetobacter Species. Bull. Agric. Chem. Soc. Jpn. 1958, 22 (6), 369386.

(5) Dutton, M. V.; Evans, C. S. Oxalate production by fungi: its role in pathogenicity and ecology in the soil environment. Can. J. Microbiol. 1996, 42 (9), 881-895.

(6) Re, L.; Maurer, B.; Ohloff, G. Ein einfacher Zugang zu 4hydroxy-2,5-dimethyl-3(2H)-furanon (furaneol), einem Aromabestandteil von Ananas und Erdbeere. Helv. Chim. Acta 1973, 56 (6), 1882-1894. 
(7) Riemenschneider, W.; Tanifuji, M. Oxalic Acid. Ullmann's Encyclopedia of Industrial Chemistry; Wiley-VCH: Weinheim, 2011.

(8) Royen, H.; Fortkamp, U. Rare Earth Elements - Purification, Separation and Recycling. Technical Report No. C211, Swedish Environmental Research Institute, September 2016.

(9) Lakshmanan, V.; Sridhar, R.; Halim, M. A. Process for extraction of rare earth elements. U.S. Patent US0283977A1, 2013.

(10) Bard, A. J.; Parsons, R.; Jordan, J. Standard potentials in aqueous solution; M. Dekker: New York, 1985.

(11) Zeng, X.; Li, J.; Shen, B. Novel approach to recover cobalt and lithium from spent lithium-ion battery using oxalic acid. J. Hazard. Mater. 2015, 295, 112-118.

(12) Sun, L.; Qiu, K. Organic oxalate as leachant and precipitant for the recovery of valuable metals from spent lithium-ion batteries. Waste Manage. (Oxford, U. K.) 2012, 32 (8), 1575-1582.

(13) Panias, D.; Taxiarchou, M.; Paspaliaris, I.; Kontopoulos, A. Mechanisms of dissolution of iron oxides in aqueous oxalic acid solutions. Hydrometallurgy 1996, 42 (2), 257-265.

(14) Panias, D.; Taxiarchou, M.; Douni, I.; Paspaliaris, I.; Kontopoulos, A. Dissolution of hematite in acidic oxalate solutions: the effect of ferrous ions addition. Hydrometallurgy 1996, 43 (1), 219-230.

(15) Taxiarchou, M.; Panias, D.; Douni, I.; Paspaliaris, I.; Kontopoulos, A. Dissolution of hematite in acidic oxalate solutions. Hydrometallurgy 1997, 44 (3), 287-299.

(16) Crouthamel, C. E.; Martin, D. S. The Solubility of Ytterbium Oxalate and Complex Ion Formation in Oxalate Solutions. J. Am. Chem. Soc. 1950, 72 (3), 1382-1386.

(17) Perry, D. L. Handbook of inorganic compounds. CRC Press: Boca Raton, FL, 2011.

(18) Rumble, J. R.; Lide, D. R.; Bruno, T. J. CRC handbook of chemistry and physics: a ready-reference book of chemical and physical data. CRC Press: Boca Raton, FL, 2018.

(19) Hall, W. T. The oxalate method for separating calcium and magnesium. J. Am. Chem. Soc. 1928, 50 (10), 2704-2707.

(20) Sarver, L. A.; Brinton, P. H. M. P. The solubilities of some rareearth oxalates. J. Am. Chem. Soc. 1927, 49 (4), 943-958.

(21) Tuncuk, A.; Stazi, V.; Akcil, A.; Yazici, E. Y.; Deveci, H. Aqueous metal recovery techniques from e-scrap: Hydrometallurgy in recycling. Miner. Eng. 2012, 25 (1), 28-37.

(22) Li, J.; Xu, Z. Environmental Friendly Automatic Line for Recovering Metal from Waste Printed Circuit Boards. Environ. Sci. Technol. 2010, 44 (4), 1418-1423.

(23) Zheng, X.; Zhu, Z.; Lin, X.; Zhang, Y.; He, Y.; Cao, H.; Sun, Z. A Mini-Review on Metal Recycling from Spent Lithium Ion Batteries. Engineering 2018, 4 (3), 361-370.

(24) Money, R. W.; Davies, C. W. The solubility of barium oxalate in aqueous salt solutions. J. Chem. Soc. 1938, No. 0, 2098-2100.

(25) William, N. S. Vanadyl Oxalate Compounds and Process for Producing Same. U.S. Patent US3689515A, 1972.

(26) Berckmans, G.; Messagie, M.; Smekens, J.; Omar, N.; Vanhaverbeke, L.; Van Mierlo, J. Cost Projection of State of the Art Lithium-Ion Batteries for Electric Vehicles Up to 2030. Energies 2017, 10 (9), 1314

(27) Lee, C. K.; Rhee, K.-I. Preparation of $\mathrm{LiCoO}_{2}$ from spent lithium-ion batteries. J. Power Sources 2002, 109 (1), 17-21.

(28) Sohn, J.-S.; Shin, S.-M.; Yang, D.-H.; Kim, S.-K.; Lee, C.-K. Comparison of Two Acidic Leaching Processes for Selecting the Effective Recycle Process of Spent Lithium ion Battery. Geosyst. Eng. 2006, 9 (1), 1-6.

(29) Zeng, X.; Li, J.; Singh, N. Recycling of Spent Lithium-Ion Battery: A Critical Review. Crit. Rev. Environ. Sci. Technol. 2014, 44 (10), 1129-1165

(30) Aaltonen, M.; Peng, C.; Wilson, B.; Lundström, M. Leaching of Metals from Spent Lithium-Ion Batteries. Recycling 2017, 2 (4), 20.

(31) Chen, C. H.; Liu, J.; Stoll, M. E.; Henriksen, G.; Vissers, D. R.; Amine, K. Aluminum-doped lithium nickel cobalt oxide electrodes for high-power lithium-ion batteries. J. Power Sources 2004, 128 (2), 278-285.
(32) Nitta, N.; Wu, F.; Lee, J. T.; Yushin, G. Li-ion battery materials: present and future. Mater. Today 2015, 18 (5), 252-264.

(33) Meshram, P.; Pandey, B. D.; Mankhand, T. R. Hydrometallurgical processing of spent lithium ion batteries (LIBs) in the presence of a reducing agent with emphasis on kinetics of leaching. Chem. Eng. J. 2015, 281, 418-427.

(34) Wang, R.-C.; Lin, Y.-C.; Wu, S.-H. A novel recovery process of metal values from the cathode active materials of the lithium-ion secondary batteries. Hydrometallurgy 2009, 99 (3), 194-201.

(35) Li, L.; Lu, J.; Zhai, L.; Zhang, X.; Curtiss, L.; Jin, Y.; Wu, F.; Chen, R.; Amine, K. A facile recovery process for cathodes from spent lithium iron phosphate batteries by using oxalic acid. CSEE J. Power Energy Syst. 2018, 4 (2), 219-225.

(36) Yang, Y.; Meng, X.; Cao, H.; Lin, X.; Liu, C.; Sun, Y.; Zhang, Y.; Sun, Z. Selective recovery of lithium from spent lithium iron phosphate batteries: a sustainable process. Green Chem. 2018, 20 (13), 3121-3133.

(37) Aikawa, T.; Watanabe, M.; Aida, T.; Smith, R. L., Jr Hydrothermal Leaching of $\mathrm{LiCoO}_{2}$ with Sulfuric Acid, Nitric Acid, and Citric Acid. Kagaku Kogaku Ronbunshu 2017, 43, 313-318.

(38) Yuliusman; Fajaryanto, R.; Nurqomariah, A.; Silvia. Silvia In Acid leaching and kinetics study of cobalt recovery from spent lithium-ion batteries with nitric acid. E3S Web of Conferences 2018, 67, 03025 .

(39) Huang, B.; Pan, Z.; Su, X.; An, L. Recycling of lithium-ion batteries: Recent advances and perspectives. J. Power Sources 2018, 399, 274-286.

(40) Zhang, X.; Bian, Y.; Xu, S.; Fan, E.; Xue, Q.; Guan, Y.; Wu, F.; $\mathrm{Li}, \mathrm{L}$; Chen, R. Innovative Application of Acid Leaching to Regenerate $\mathrm{Li}\left(\mathrm{Ni}_{1 / 3} \mathrm{Co}_{1 / 3} \mathrm{Mn}_{1 / 3}\right) \mathrm{O}_{2}$ Cathodes from Spent LithiumIon Batteries. ACS Sustainable Chem. Eng. 2018, 6 (5), 5959-5968.

(41) Ilhan, S. Leaching of Spent Ni-Mo Hydrodesulphurization (HDS) Catalyst in Oxalic Acid Solutions. Proceedings of the 3rd Pan American Materials Congress; Springer International Publishing: 2017; pp 557-564.

(42) Szymczycha-Madeja, A. Kinetics of Mo, Ni, V and Al leaching from a spent hydrodesulphurization catalyst in a solution containing oxalic acid and hydrogen peroxide. J. Hazard. Mater. 2011, 186 (2), 2157-2161.

(43) Horeh, N. B.; Mousavi, S. M.; Shojaosadati, S. A. Bioleaching of valuable metals from spent lithium-ion mobile phone batteries using Aspergillus niger. J. Power Sources 2016, 320, 257-266.

(44) Deng, B.; Wang, B.; Su, S.; Ding, S.; Sun, W. Recovery of Iron from Pyrolusite Leaching Slag by a Lab-Scale Circulation Process of Oxalic Acid Leaching and Ultraviolet Irradiation. Metals 2018, 8 (2), 8.

(45) Wu, W.; Wang, C.; Bao, W.; Li, H. Selective reduction leaching of vanadium and iron by oxalic acid from spent $\mathrm{V}_{2} \mathrm{O}_{5}-\mathrm{WO}_{3} / \mathrm{TiO}_{2}$ catalyst. Hydrometallurgy 2018, 179, 52-59.

(46) Park, Y. M.; Lim, H.; Moon, J.-H.; Lee, H.-N.; Son, S. H.; Kim, H.; Kim, H.-J. High-Yield One-Pot Recovery and Characterization of Nanostructured Cobalt Oxalate from Spent Lithium-Ion Batteries and Successive Re-Synthesis of $\mathrm{LiCoO}_{2}$. Metals 2017, 7 (8), 303.

(47) Nayaka, G. P.; Manjanna, J.; Pai, K. V.; Vadavi, R.; Keny, S. J.; Tripathi, V. S. Recovery of valuable metal ions from the spent lithiumion battery using aqueous mixture of mild organic acids as alternative to mineral acids. Hydrometallurgy 2015, 151, 73-77.

(48) Chen, X.; Luo, C.; Zhang, J.; Kong, J.; Zhou, T. Sustainable Recovery of Metals from Spent Lithium-Ion Batteries: A Green Process. ACS Sustainable Chem. Eng. 2015, 3 (12), 3104-3113.

(49) Hu, C.; Guo, J.; Wen, J.; Peng, Y. Preparation and Electrochemical Performance of Nano- $\mathrm{Co}_{3} \mathrm{O}_{4}$ Anode Materials from Spent Li-Ion Batteries for Lithium-Ion Batteries. J. Mater. Sci. Technol. 2013, 29 (3), 215-220.

(50) Chianelli, R. R. Fundamental Studies of Transition Metal Sulfide Hydrodesulfurization Catalysts. Catal. Rev.: Sci. Eng. 1984, 26 (3-4), 361-393. 
(51) Dhar, G. M.; Srinivas, B. N.; Rana, M. S.; Kumar, M.; Maity, S. K. Mixed oxide supported hydrodesulfurization catalysts-a review. Catal. Today 2003, 86 (1), 45-60.

(52) Masuda, C.; Yonezu, K.; Watanabe, K.; Yokoyama, T. Recovery of Platinum from Spent Reforming Catalyst by Acid Leaching and Coprecipitation. Proc. Earth Planet. Sci. 2013, 6, 435-440.

(53) Mazurek, K. Recovery of vanadium, potassium and iron from a spent vanadium catalyst by oxalic acid solution leaching, precipitation and ion exchange processes. Hydrometallurgy 2013, 134-135, 26-31.

(54) Erust, C.; Akcil, A.; Bedelova, Z.; Anarbekov, K.; Baikonurova, A.; Tuncuk, A. Recovery of vanadium from spent catalysts of sulfuric acid plant by using inorganic and organic acids: Laboratory and semipilot tests. Waste Manage. (Oxford, U. K.) 2016, 49, 455-461.

(55) Akcil, A.; Vegliò, F.; Ferella, F.; Okudan, M. D.; Tuncuk, A. A review of metal recovery from spent petroleum catalysts and ash. Waste Manage. (Oxford, U. K.) 2015, 45, 420-433.

(56) Delmas, F.; Nogueira, C.; Dalrymple, I.; Parkes, J. Metals Recovery From Hydrodesulphurization Catalysts. Hydrometallurgy '94; Springer: Dordrecht, The Netherlands, 1994; pp 1075-1086.

(57) Menoufy, M. F.; Ahmed, H. S. Treatment and Reuse of Spent Hydrotreating Catalyst. Energy Sources, Part A 2008, 30 (13), 12131222.

(58) Al-Sheeha, H.; Marafi, M.; Raghavan, V.; Rana, M. S. Recycling and Recovery Routes for Spent Hydroprocessing Catalyst Waste. Ind. Eng. Chem. Res. 2013, 52 (36), 12794-12801.

(59) Zou, H.; Gratz, E.; Apelian, D.; Wang, Y. A novel method to recycle mixed cathode materials for lithium ion batteries. Green Chem. 2013, 15, 1183-1191.

(60) Winterbourn, C. C. Toxicity of iron and hydrogen peroxide: the Fenton reaction. Toxicol. Lett. 1995, 82-83, 969-974.

(61) Lee, F. M.; Knudsen, R. D.; Kidd, D. R. Reforming catalyst made from the metals recovered from spent atmospheric resid desulfurization catalyst. Ind. Eng. Chem. Res. 1992, 31 (2), 487-490.

(62) Aung, K. M. M.; Ting, Y.-P. Bioleaching of spent fluid catalytic cracking catalyst using Aspergillus niger. J. Biotechnol. 2005, 116 (2), $159-170$.

(63) Santhiya, D.; Ting, Y.-P. Bioleaching of spent refinery processing catalyst using Aspergillus niger with high-yield oxalic acid. J. Biotechnol. 2005, 116 (2), 171-184.

(64) Valverde, I. M.; Paulino, J. F.; Afonso, J. C. Hydrometallurgical route to recover molybdenum, nickel, cobalt and aluminum from spent hydrotreating catalysts in sulphuric acid medium. J. Hazard. Mater. 2008, 160 (2), 310-317.

(65) Fleming, C. A. Hydrometallurgy of precious metals recovery. Hydrometallurgy 1992, 30 (1), 127-162.

(66) Sullivan, J. D. Leaching copper from its ores. J. Chem. Educ. 1931, 8 (5), 829.

(67) Posel, J. G.; Williams, G. P.; Nilsen, D. N. Recovery of nitric acid soluble transition metals from sulfur and iron containing ores of the same. U.S. Patent US3966462A, 1976.

(68) Agacayak, T.; Zedef, V. Leaching of a Turkish Lateritic Nickel Ore in Nitric Acid Solution. In Mine Planning and Equipment Selection, 2014; Drebenstedt, C., Singhal, R., Eds.; Springer: 2014; pp 10391045.

(69) Corbin, D. R.; Griffin, T. P.; Hutchenson, K. W.; Li, S.; Shiflett, M. B.; Torardi, C.; Zaher, J. J. Processes for producing titanium dioxide. U.S. Patent US8137647B2, 2012.

(70) Corbin, D. R.; Hutchison, S. N. Processes for producing titanium dioxide. U.S. Patent US7678350B2, 2010.

(71) Tzeferis, P. G.; Agatzini-Leonardou, S. Leaching of nickel and iron from Greek non-sulphide nickeliferous ores by organic acids. Hydrometallurgy 1994, 36 (3), 345-360.

(72) Kursunoglu, S.; Kaya, M. Dissolution behavior of Caldag lateritic nickel ore subjected to a sequential organic acid leaching method. Int. J. Miner., Metall. Mater. 2015, 22 (11), 1131-1140.

(73) Sahu, S.; Kavuri, N. C.; Kundu, M. Dissolution kinetics of nickel laterite ore using different secondary metabolic acids. Braz. J. Chem. Eng. 2011, 28, 251-258.
(74) Kragten, J. Atlas of metal- ligand equilibria in aqueous solution; Ellis Horwood Ltd., distributed by J. Wiley \& Sons: New YorkLondon-Sydney-Toronto, 1978.

(75) Ghosh, S.; Paul, A. K. Bioleaching of nickel by Aspergillus humicola SKP102 isolated from Indian lateritic overburden. J. Sustainable Mining 2016, 15 (3), 108-114.

(76) Das, A. P.; Swain, S.; Panda, S.; Pradhan, N.; Sukla, L. B. Reductive Acid Leaching of Low Grade Manganese Ores. Geomaterials 2012, 2, 70-72.

(77) Sahoo, R. N.; Naik, P. K.; Das, S. C. Leaching of manganese from low-grade manganese ore using oxalic acid as reductant in sulphuric acid solution. Hydrometallurgy 2001, 62 (3), 157-163.

(78) Azizi, D.; Shafaei, S. Z.; Noaparast, M.; Abdollahi, H. Modeling and optimization of low-grade $\mathrm{Mn}$ bearing ore leaching using response surface methodology and central composite rotatable design. Trans. Nonferrous Met. Soc. China 2012, 22 (9), 2295-2305.

(79) El Hazek, M. N.; Gabr, A. A. Dissolution of Manganese from Polymetallic Material Using Sulfuric-Oxalic Acid Medium. Am. J. Anal. Chem. 2016, 7, 469-477.

(80) Kalpakli, A. O.; Ilhan, S.; Kahruman, C.; Yusufoglu, I. Dissolution behavior of calcium tungstate in oxalic acid solutions. Hydrometallurgy 2012, 121-124, 7-15.

(81) Osthoff, R. C. Process for extracting tungsten values. U.S. Patent US2942940, 1956.

(82) Davey, T.; Albert, R. Method of extracting tungsten values from tungsten containing ores. U.S. Patent WO8800249, 1990.

(83) Yang, Y.; Wang, X.; Wang, M.; Wang, H.; Xian, P. Recovery of iron from red mud by selective leach with oxalic acid. Hydrometallurgy 2015, 157, 239-245.

(84) Lee, S. O.; Tran, T.; Jung, B. H.; Kim, S. J.; Kim, M. J. Dissolution of iron oxide using oxalic acid. Hydrometallurgy 2007, 87 (3), 91-99.

(85) Vakilchap, F.; Mousavi, S. M.; Shojaosadati, S. A. Role of Aspergillus niger in recovery enhancement of valuable metals from produced red mud in Bayer process. Bioresour. Technol. 2016, 218, 991-998.

(86) Gyliene, O.; Salkauskas, M. Metal recovery from spent electroless plating solutions by oxalate precipitation. Plat. Surf. Finish. 1995, 82 (10), 61-63.

(87) Gylienè, O.; Šalkauskas, M.; Juškenas, R. The use of organic acids as precipitants for metal recovery from galvanic solutions. $J$. Chem. Technol. Biotechnol. 1997, 70 (1), 111-115.

(88) Lee, K. R.; Kim, J.; Jang, J. G. Recovery of zinc in spent pickling solution with oxalic acid. Korean Chem. Eng. Res. 2017, 55 (6), 785790.

(89) Yu, B.; Hse, C. Y.; Shupe, T. F. Rapid microwave-assisted acid extraction of metals from chromated copper arsenate (CCA)-treated southern pine wood. 40th Annual Meeting of the International Research Group on Wood Protection, Beijing, China, 2009.

(90) Wei, M.; Chen, J.; Wang, X. Removal of arsenic and cadmium with sequential soil washing techniques using $\mathrm{Na}_{2}$ EDTA, oxalic and phosphoric acid: Optimization conditions, removal effectiveness and ecological risks. Chemosphere 2016, 156, 252-261.

(91) Ash, C.; Tejnecký, V.; Borůvka, L.; Drábek, O. Different lowmolecular-mass organic acids specifically control leaching of arsenic and lead from contaminated soil. J. Contam. Hydrol. 2016, 187, 1830.

(92) Shupe, T. F.; Hse, C. Y.; Pan, H. New Approach to Remove Metals from Chromated Copper Arsenate (CCA)-Treated Wood. 55th International Convention of Society of Wood Science and Technology, Beijing, China, 2012.

(93) Agatzini-Leonardou, S.; Oustadakis, P.; Tsakiridis, P. E.; Markopoulos, C. Titanium leaching from red mud by diluted sulfuric acid at atmospheric pressure. J. Hazard. Mater. 2008, 157 (2), 579586.

(94) Malden, P. J.; Windle, W. Method of improving the whiteness of clays. U.S. Patent US3482685, 1969. 
(95) Hernández, R. A. H.; García, F. L.; Cruz, L. E. H.; Luévanos, A. M. Iron removal from a kaolinitic clay by leaching to obtain high whiteness index. IOP Conf. Ser.: Mater. Sci. Eng. 2013, 45, 012002.

(96) Veglio, F.; Passariello, B.; Barbaro, M.; Plescia, P.; Marabini, A. $\mathrm{M}$. Drum leaching tests in iron removal from quartz using oxalic and sulphuric acids. Int. J. Miner. Process. 1998, 54, 183-200.

(97) Vegliò, F.; Passariello, B.; Abbruzzese, C. Iron Removal Process for High-Purity Silica Sands Production by Oxalic Acid Leaching. Ind. Eng. Chem. Res. 1999, 38 (11), 4443-4448.

(98) Baumgartner, E.; Blesa, M. A.; Marinovich, H.; Maroto, A. J. G. Heterogeneous electron transfer as a pathway in the dissolution of magnetite in oxalic acid solutions. Inorg. Chem. 1983, 22 (16), 22242226.

(99) Lee, S.-O.; Kim, W.-T.; Oh, J.-K.; Shin, B.-S. Iron-removal of Clay Mineral with Oxalic Acid. Shigen to Sozai 1997, 113 (11), 847851.

(100) Lee, S.-O.; Oh, J.-k.; Shin, B.-S. Dissolution of Iron Oxide Rust Materials using Oxalic Acid. Shigen to Sozai 1999, 115 (11), 815-819.

(101) Ubaldini, S.; Piga, L.; Fornari, P.; Massidda, R. Removal of iron from quartz sands: A study by column leaching using a complete factorial design. Hydrometallurgy 1996, 40 (3), 369-379.

(102) Oviedo, C.; Rodríguez, J. EDTA: the chelating agent under environmental scrutiny. Quim. Nova 2003, 26, 901-905.

(103) Oustan, S.; Heidari, S.; Neyshabouri, M.; Reyhanitabar, A.; Bybordi, A. Removal of heavy metals from a contaminated calcareous soil using oxalic and acetic acids as chelating agents. International Conference on Environment Science and Engineering, 2011; pp 152-155.

(104) Ibrahim, L. Experimental study for heavy metals mitigation in polluted soil. J. Agric. Sci. Rev. 2015, 4, 119-126.

(105) Tandy, S.; Bossart, K.; Mueller, R.; Ritschel, J.; Hauser, L.; Schulin, R.; Nowack, B. Extraction of Heavy Metals from Soils Using Biodegradable Chelating Agents. Environ. Sci. Technol. 2004, 38 (3), 937-944.

(106) Norton, S. K. Lost Seasonality and Overconsumption of Plants: Risking Oxalate Toxicity. J. Evol. Health 2018, 2 (3), 4.

(107) Christison, R; Coindet, C. W. An experimental inquiry on poisoning by oxalic acid. Edinburgh Med. Surg. J. 1823, 19 (76), 323.

(108) Tallqvist, H.; Vaananen, I. Death of a child from oxalic acid poisoning due to eating rhubarb leaves. Ann. Paediatric. Fenniae 1960, $6,144-147$.

(109) Noonan, S.; Savage, G. Oxalate content of foods and its effect on humans. Asia Pac. J. Clin. Nutr. 1999, 8 (1), 64-74.

(110) Massey, L. K.; Roman-Smith, H.; Sutton, R. A. L. Effect of dietary oxalate and calcium on urinary oxalate and risk of formation of calcium oxalate kidney stones. J. Am. Diet. Assoc. 1993, 93 (8), 901906.

(111) Duan, X.; Qu, M.; Wang, J.; Trevathan, J.; Vrtiska, T.; Williams, J. C.; Krambeck, A.; Lieske, J.; McCollough, C. Differentiation of Calcium Oxalate Monohydrate and Calcium Oxalate Dihydrate Stones Using Quantitative Morphological Information from Micro-Computerized and Clinical Computerized Tomography. J. Urol. 2013, 189 (6), 2350-2356.

(112) Lewis, R. J. Sax's dangerous properties of industrial materials, 12th ed.; Wiley: Hoboken, NJ, 2004.

(113) Bureau of Alcohol, Tobacco, Firearms, and Explosives, U.S. Department of Justice. 2017 Annual List of Explosive Materials, https://www.federalregister.gov/documents/2017/12/28/2017$28010 /$ commerce-in-explosives-2017-annual-list-of-explosivematerials (accessed Feb 17, 2019).

(114) Hart, P. Explosive properties of oxalate of peroxide of mercury. Am. J. Pharm. 1860, 416.

(115) Berthelot, M.; Hake, C. N.; Macnab, W. Explosives and their power; Kessinger Press: 2010. 